\title{
Optimization of xylanase from Pseudomonas mohnii isolated from Simlipal Biosphere Reserve, Odisha, using response surface methodology
}

\author{
Manish Paul ${ }^{\dagger}$, Dipti Pravamayee Nayak ${ }^{\dagger}$ and Hrudayanath Thatoi ${ }^{*}$ (D)
}

\begin{abstract}
Background: Xylanase has long been recognized as a widely used industrially important enzyme. There are some bacterial species already reported to produce xylanase which have potent xylanolytic activity towards the use of this enzyme in the production of bioethanol from lignocellulosic biomass. In this view, an efficient xylanolytic bacterial strain was isolated and screened from the soil sample of Simlipal Biosphere Reserve. Enzymatic assay for the xylanase activity was evidenced from the most potent bacterial strain, and the culture condition was optimized for obtaining the maximum enzyme activity. The most potent xylanolytic strain was also identified using biochemical and molecular methods.
\end{abstract}

Results: Nineteen xylanolytic bacteria (SXB1-SXB19) were isolated from Simlipal forest soil samples following dilution plate technique using corn cob xylan-enriched nutrient agar medium and screened for their xylanaseproducing ability. Among these isolates, SXB19 showed maximum xylanolytic potential with a halozone size of 2.5 $\mathrm{cm}$ as evident in the formation of prominent yellow patches surrounding its growth in xylan-enriched nutrient agar plate. In unoptimized condition, SXB19 showed the highest enzymatic activity of $22.5 \mathrm{IU} / \mathrm{ml}$ among the 19 bacterial strains. In order to optimize the culture conditions for maximizing the xylanase production, Box-Behnken design of response surface methodology (RSM) was used. Four variables such as incubation time, pH, substrate (corn cob xylan) concentration, and temperature were considered for the RSM optimization study. From the results, it is evident that in an optimized condition of incubation time $36 \mathrm{~h}, \mathrm{pH} 6.0$, xylan concentration $0.5 \%$, and temperature $42.5^{\circ} \mathrm{C}$, the enzyme activity reached a maximum of $152 \mathrm{IU} / \mathrm{ml}$ with nearly 6.75 times increase from the unoptimised condition. Besides, xylanase production from SXB19 was considerable in the presence of xylan followed by starch, nitrogen source such as urea followed by yeast extract, and mineral ion sources such as $\mathrm{KCl}$ followed by $\mathrm{MgSO}_{4}$ and $\mathrm{ZnSO}_{4}$. From different biochemical tests, $16 \mathrm{~S}$ rRNA gene sequencing, and phylogenetic analysis, the bacterial strain SXB19 was identified as Pseudomonas mohnii.

Conclusion: The isolation of Pseudomonas mohnii, a potent xylanolytic bacterium from Simlipal, is a new report which opens up an opportunity for industrial production of xylanase for bioethanol production and other applications.

Keywords: Lignocellulosic biomass, Xylanase production, Corn cob xylan, Xylanase, Pseudomonas mohnii, Response surface methodology

\footnotetext{
* Correspondence: hnthatoi@gmail.com

${ }^{+}$Manish Paul and Dipti Pravamayee Nayak contributed equally to this work. Department of Biotechnology, North Orissa University, Takatpur, Baripada, Odisha 757003 , India
}

\section{Springer Open}

(ㅇ The Author(s). 2020 Open Access This article is licensed under a Creative Commons Attribution 4.0 International License, which permits use, sharing, adaptation, distribution and reproduction in any medium or format, as long as you give appropriate credit to the original author(s) and the source, provide a link to the Creative Commons licence, and indicate if changes were made. The images or other third party material in this article are included in the article's Creative Commons licence, unless indicated otherwise in a credit line to the material. If material is not included in the article's Creative Commons licence and your intended use is not permitted by statutory regulation or exceeds the permitted use, you will need to obtain permission directly from the copyright holder. To view a copy of this licence, visit http://creativecommons.org/licenses/by/4.0/. 


\section{Background}

In recent years, there is a tremendous pressure on world fossil fuel supply and reserve [1]. The demand for fossil fuel is increasing day by day, and the available resources are rapidly decreasing indicating that soon, it will be disappeared [2]. The International Energy Agency (IEA) predicts that the world's energy demand will increase by more than 55\% between 2005 and 2030, and oil demand is projected to grow from some 85 million barrels per day currently to some 120 million barrels per day by 2030 [3]. It is also known that the large-scale use of fossil fuels all over the world increase $\mathrm{CO}_{2}$ level and accumulate greenhouse gasses which make the environment polluted and unsustainable [2]. To maintain the sustainability of fuel demand and cleanliness of the environment, there is an urgent need of producing renewable and environment-friendly fuels [4].

In this context, biofuel seems to be an alternative to fossil fuel which has reduced impact on environment pollution [5]. The global production and use of biofuels like bioethanol and biodiesel as the alternative energy source have shown to significantly promote in recent years among which only bioethanol covers $85 \%$.

Bioethanol can be produced from different biomass feedstocks containing fermentable sugars or complex carbohydrates through appropriate fermentation technology. These feedstocks can be classified into three groups, which are sugary crops, starchy crops, and lignocellulosic biomass [6]. The bioethanol production from sugary and starchy crops is known as the firstgeneration bioethanol while that of lignocellulosic biomass is considered as the second-generation bioethanol. First-generation biofuel production comprises food crops such as maize, rice, wheat, barley, potato, sugarcane, and vegetable oil, for example, soybean oil, sunflower oil, olive oil, canola oil, and mustard oil. The production of first-generation bioethanol is generally assumed to be one of the main causes of scarcity of food staff. Therefore, the recent research efforts have been focused on lignocellulosic biomasses, the secondgeneration bioethanol, as they are mostly waste materials, available at a low price, rich in carbohydrates, and noncompetitive with the food chain [7].

Presently, researchers are directed on developing multiple processes to produce biofuel energy from lignocellulosic biomass [8]. Lignocellulosic biomass consists of plant cell walls whose primary structural components are polysaccharides such as cellulose, hemicellulose, and heterogeneous polyphenolic substance like lignin. Among these three, cellulose and hemicellulose are converted to ethanol through fermentation whereas lignin is recalcitrant in nature and it actively inhibits fermentation. However, the components of lignocellulosic biomass vary substantially, according to plant species, soil fertility, fertilization practice, and climate. For agricultural residues such as rice straw, wheat, and corn stover, the plant cell wall was reported to contain about $40 \%$ cellulose, 30\% hemicelluloses, and 15\% lignin [9].

Cellulose is a homopolymer of hexose sugar glucose which is the main contributor for bioethanol production followed by hemicelluloses. Hemicellulose is a combination of different polysaccharides and is mainly composed of pentose sugars such as xylose and arabinose. This polysaccharide can be easily degraded into monosaccharides such as xylose, galactose, fructose, dextrose, arabinose, and mannose because of its low degree of polymerization [10-12]. Xylan is a polysaccharide and a major component of hemicelluloses in plants which is made of xylose molecules. Next to cellulose, xylan is the second most abundant renewable polysaccharide in nature and is responsible to hold the plant cell wall together. Complete hydrolysis of xylan to xylose needs a complex of xylanolytic enzymes such as endoxylanase, $\beta$-xylosidase, $\alpha$-arabinofuranosidase, acetyl esterase, and $\alpha$-glucuronidase. Since hemicullulose hydrolysis is an important step in bioethanol production, isolation and evaluation of hemicellulase enzyme-producing microorganisms have been an important field of research in this essence.

Xylanase (E.C.3.2.1.8) is the class of glycosyl hydrolases enzymes which hydrolyze hemicellulose by degrading the linear polysaccharide $\beta-1,4$ xylan to xylose [13]. Xylanase has a wide range of applications in biotechnology which include bio-pulping of wood, bleaching of pulp [14], processing of foods [15], and conversion of lignocellulosic substances into bioethanol [16]. In comparison with a chemical pretreatment, the microbial xylanase enzyme has a low environmental impact and hence more eco-friendly during the applications in the abovementioned industrial purposes [17]. Xylanasemediated hydrolysis of lignocellulosic biomass reported to produce oligosaccharides which are further used as functional food additives or alternative sweeteners with beneficial properties [18]. One of the critically important enzymatic activities required for the depolymerization of xylans is endo- $1,4-\beta$-xylanase activity. These enzymes cleave the $\beta-1,4$ glycosidic linkage between xylose residues in the backbone of xylans present in lignocellulosic biomass [19]. Xylanase is produced by many microorganisms such as bacterial as well as fungal species. This enzyme plays a significant role in such microorganisms that live on plant sources for the degradation of plant materials into usable nutrients [20]. Hence, it is important to isolate and identify xylanase-producing microorganisms from the natural environment and evaluate their bioethanol production ability, an important field of biotechnology research. Forest soil can harbor a large number of lignocellulolytic microorganisms including 
xylanase-producing one due to the availability of huge quantities of lignocellulosic biomasses and can be explored for xylanolytic bacteria. Numerous physicochemical factors serve as the catalyst during the action of xylanase enzyme which in turn enhance the quality of enzyme and its mass production and substrate specificity as well even in extreme conditions such as high temperature, high or low $\mathrm{pH}$, and high or low salinity [21]. Xylanase can be produced by two main methods, e.g., solid-state fermentation and submerged fermentation, where all the parameters can be controlled and manipulated for the purpose of mass production of the enzyme [22, 23].

Keeping these in view, the present study aims at isolating and screening an efficient xylanase-producing bacterium from the soil samples of Simlipal Biosphere Reserve (SBR), located in the northern part of Odisha, India, and to optimize the xylanase production ability of that bacterium using the response surface method for its possible use in bioethanol production from lignocellulosic biomasses.

\section{Methods}

\section{Collection and storage of soil sample}

Soil samples were collected from different locations from two forest sites viz. Sitakund and Lulung of Simlipal Biosphere Reserve $\left(21^{\circ} 10^{\prime}\right.$ to $22^{\circ} 12^{\prime} \mathrm{N}$ latitude and $85^{\circ} 58^{\prime}$ to $86^{\circ} 42^{\prime}$ E longitude), located in Mayurbhanj district in Odisha, India. The reserve is a compact mass of natural forest spread over a total area of $5569 \mathrm{~km}^{2}$ with a core area of $845 \mathrm{~km}^{2}$ and a buffer zone of $2129 \mathrm{~km}^{2}$ comprising 16 forest ranges that surrounds a transitional zone of $2595 \mathrm{~km}^{2}$ [24]. About a $1-\mathrm{cm}$ top layer of soil was removed during the collection of soil samples. The soil samples were packed in sterile polythene bags and kept in an ice box. Then, these samples were transported to the laboratory and stored at $4{ }^{\circ} \mathrm{C}$ for conducting further experiments.

\section{Isolation of xylanolytic bacteria}

One gram of soil sample was measured aseptically and transferred to a $250-\mathrm{ml}$ flask containing $100-\mathrm{ml}$ sterile water and covered with an aluminum foil. The flask was shaken for 15-20 min in an orbital shaker to make the stock solution having a dilution of $10^{-2}$. One-milliliter suspension from stock solution was added in $9 \mathrm{ml}$ of sterilized water taken in a sterile test tube, and suspension was then serially diluted to obtain $10^{-5}$ or $10^{-6}$ dilutions. The suspension with $10^{-5}$ or $10^{-6}$ dilutions was then used as inoculums for pour plating performed in a laminar air flow by using corn cob xylan-enriched (obtained from Sisco Research Laboratories Pvt. Ltd. (SRL), India) nutrient agar (g/100 ml: nutrient broth, $1.3 \mathrm{~g}$; agar, $2 \mathrm{~g}$ ) medium. Inoculated plates were incubated at a $37^{\circ} \mathrm{C}$ temperature in a bacterial incubator for $48 \mathrm{~h}$ to obtain xylanolytic bacterial colonies.

\section{Screening of xylanolytic bacteria}

Screening of xylanolytic activity of bacterial isolates was carried out in nutrient agar medium containing $0.5 \%$ of corn cob xylan. For this purpose, pure cultures of selected colonies were prepared through repeated streak plating, and a loopful of culture from the pure cultures was inoculated on nutrient broth xylan medium and broth cultures were incubated for $18 \mathrm{~h}$. Ten microliters of each bacterial culture (intact bacterial cell in broth) was inoculated inside a 4-mm pore made on the xylan agar plates. Xylan agar plates containing bacterial inoculums were then incubated at $37^{\circ} \mathrm{C}$ for $72 \mathrm{~h}$. Plates were stained by $0.1 \%$ Congo red solution and kept for $1 \mathrm{~h}$ followed by destaining using $1 \mathrm{M} \mathrm{NaCl}$ for $15 \mathrm{~min}$ for determination of xylan hydrolyzing zone surrounding the bacterial growth on xylan agar plates [25]. After destaining, xylan hydrolyzing halo zone $(H)$ and colony diameter $(C)$ were measured for the individual bacterial strain to calculate hydrolysis index $(H: C)$.

\section{Determination of bacterial xylanase activity}

Xylanase activity of the isolated xylanolytic bacteria was determined by the DNS method [26]. Nineteen bacteria showing distinct hydrolyzing zone on xylan-enriched nutrient agar plates were selected as Simlipal xylanase bacteria and designated as SXB1 to SXB19. The amount of reducing sugar hydrolyzed by the xylanase activity of all the nineteen xylanolytic bacterial isolates (SXB1-SXB19) was measured which showed a xylan-hydrolyzing zone surrounding their growth. After an incubation of $24 \mathrm{~h}$, freshly cultured bacterial broths of each xylanolytic bacterial isolates were individually transferred to a sterile 1.5-ml eppendorf tube. Each eppendorf tube was centrifuged at $10,000 \mathrm{rpm}$ for $10 \mathrm{~min}$ at $4{ }^{\circ} \mathrm{C}$. After centrifugation, the supernatant formed in each eppendorf tube was separated carefully using pipettes from the pellets and used to prepare the reaction mixture for enzyme assay. The substrate solution was prepared by adding $1 \%$ of corncob xylan with phosphate buffer $(0.1 \mathrm{M})$ at $\mathrm{pH} 6.8$. Substrate solution of $0.5 \mathrm{ml}$ and each bacterial supernatant (crude enzyme) of $0.5 \mathrm{ml}$ were taken in an assay tube to make $1-\mathrm{ml}$ reaction mixture. Assay tubes containing the reaction mixture were then incubated at $55^{\circ} \mathrm{C}$ for $15 \mathrm{~min}$ in a water bath. After the incubation, $1.5 \mathrm{ml}$ of DNS solution was mixed to each assay tube and boiled at $100^{\circ} \mathrm{C}$ for $10 \mathrm{~min}$ to stop the reaction. The amount of reducing sugar released in the hydrolysis by each bacterial supernatant was measured using a UVVIS spectrophotometer (Systronic-119) at an absorbance value of $540 \mathrm{~nm}$. One unit (IU) of xylanase activity was measured as $1 \mu \mathrm{Mol}$ of xylose liberated per milliliter of 
enzyme per minute. For the enzyme assay, the reaction control was prepared without a bacterial supernatant (crude enzyme) and was simultaneously run under the DNS protocol for comparison with other samples.

\section{Growth curve analysis}

The growth curve was studied for the most efficient bacterial strain SXB19 that showed the highest xylanolytic activity. One loopful of pure culture was transferred into $100 \mathrm{ml}$ of sterile xylan-enriched media in a conical flask and kept in an incubator. A control containing $100 \mathrm{ml}$ xylan broth was also prepared without inoculating the bacterial culture and was analyzed simultaneously with the inoculated sample for comparison. The culture was taken at regular 2-h intervals for $42 \mathrm{~h}$ to determine the bacterial growth by measuring the absorbance at $600 \mathrm{~nm}$ using a UV-Vis spectrophotometer. A growth curve of cell concentration against time was plotted using the obtained absorbance values. Xylanase activity was also measured at $2 \mathrm{~h}$ intervals during bacterial growth using the DNS method as described above.

\section{Phenotypic characterization of xylanase-degrading bacteria}

For phenotypic identification, morphological and biochemical studies were undertaken. To study the morphology, Gram's staining was carried out for the xylanolytic bacterium SXB19. After Gram's staining, the bacterium was observed under a phase-contrast microscope ( $\times 100$ objectives) to determine its shape, size, and response to Gram stain (Gram positive or Gram negative).

\section{Biochemical characterization of xylanolytic bacteria}

The bacterial strain SXB19 was further subjected to biochemical tests as per Bergey's Manual of Systematic Bacteriology [27]. These tests are useful for the identification of the unknown bacterium. A number of biochemical tests such as catalase test, oxidase test, urease test, methyl red test, Voges-Prausker test, citrate utilization test, carbohydrate metabolism test, oxidation/fermentation test, indole test, hydrogen sulfide $\left(\mathrm{H}_{2} \mathrm{~S}\right)$ test, gelatin hydrolysis test, and coagulase test were performed.

\section{Molecular identification of xylanolytic bacteria}

Molecular identification of the most potent xylanolytic strain SXB19 was done by $16 \mathrm{~S}$ rRNA gene sequencing. DNA of the SXB19 bacterial strain was extracted using standard methods [28]. The 16S rRNA gene was amplified by PCR using universal primers 27F (5' -AGAGTT TGATCCTGGCTCAG-3') and 1492R (5'-GGTTACCT TGTTACGACTT-3'). Amplified 16S rRNA gene was then purified using a Gel DNA extraction kit (Qiagen,
Seoul, South Korea) and sent for sequencing to Applied Bioscience Eurofins, Bangalore.

\section{Construction of phylogenetic tree}

Using the forward and reverse sequence data of the bacterium SXB19 obtained from 16S rRNA gene sequencing, a consensus $16 \mathrm{~S}$ rRNA gene sequence of the bacterium was generated by the CAP3 web server [29]. Other homolog $16 \mathrm{~S}$ rRNA gene sequences were compared with the consensus sequence generated for the SXB19 isolate using the BLASTN tool (https://blast.ncbi. nlm.nih.gov/Blast.cgi) available at the GenBank database of the NCBI server. The closely related homolog sequences were considered for both the pair-wise and multiple sequence alignment. Pair-wise and multiple sequence alignment using the ClustalW tool were performed, and the output of alignment was used for the construction of phylogenetic tree in the MEGA 7.0.26 (Molecular Evolutionary Genetics Analysis) software using the neighbor-joining (NJ) [30].

\section{Evaluation of carbon, nitrogen, and metal sources in xylanase production by SXB19 bacterium}

To select the preferable carbon and nitrogen sources to enhance the production of xylanase enzyme by the bacterium SXB19, the bacterium was grown separately in a medium supplemented with different carbon sources such as glucose, sucrose, fructose, starch, and nitrogen sources such as yeast extract, urea, sodium nitrate, ammonium nitrate, and peptone in a concentration of $0.4 \%$ (w/v). Further, metal ion sources such as $\mathrm{CoCl}_{2}, \mathrm{CaCl}_{2}$, $\mathrm{MgSO}_{4}, \mathrm{MnSO}_{4}, \mathrm{CuSO}_{4}, \mathrm{FeSO}_{4}, \mathrm{KCl}$, and $\mathrm{ZnSO}_{4}$ were also added individually in a concentration of $0.1 \% \mathrm{w} / \mathrm{v}$ to the bacterial growth medium to determine their role on enzyme activity [31]. To assess the effect of various carbon sources on enzyme production, corncob xylan in the basal medium was replaced with other carbon sources, such as glucose, fructose, sucrose, and starch. In addition, corncob xylan was also tested as a carbon source as control. For the determination of the role of different nitrogen sources on enzyme production, tryptone and peptone in the basal medium were replaced with yeast extract, urea, sodium nitrate, and ammonium nitrate. In case of the determination of the effect of metal ion sources on enzyme production, $\mathrm{K}_{2} \mathrm{HPO}_{4}$ and $\mathrm{NaCl}$ were supplemented with other metal ion sources that have been mentioned earlier.

\section{Optimization of xylanase enzyme production Experimental design and statistical optimization of xylanase production using RSM}

A Box-Behnken design was used to investigate the combined effect of four variables such as incubation time, $\mathrm{pH}$, xylan concentration, and temperature on xylanase 
enzyme production. Different degrees of the variables $(\mathrm{A}, \mathrm{B}, \mathrm{C}$, and $\mathrm{D})$ at three levels $(+1,0,-1)$ were used in the experimental design and are presented in Table 1. The independent variables were coded -1 and +1 as low and high levels, respectively [32]. The Box-Behnken design is most widely used for the preparation of quadratic response surfaces and a second-degree polynomial model to analyze the pattern of enzyme production. This second-degree polynomial model is used for process optimization by carrying out a set of experimental runs [33]. Box-Behnken designs are used to generate higherorder response surfaces using fewer required runs than a normal factorial technique. This technique essentially suppresses selected runs in an attempt to maintain the higher-order surface definition. The Design-Expert (version 12, Stat-Ease Inc., Minneapolis, USA) statistical software was used to develop the experimental design for optimizing the growth condition to obtain maximum xylanase activity. The experimental design is set up on a number of runs $(N)$ according to the following equation: $N=k^{2}+k+C_{p}$, where $k$ and $C_{p}$ are the factor number and replications number which are 4 and 3 , respectively, in the present study. The predicted model using the second-degree polynomial equation resulted in 27 different experimental runs in the current work. The seconddegree polynomial equation for the predicted model can be represented as follows:

$$
\begin{aligned}
Y= & b_{0}+b_{1} \mathrm{~A}+b_{2} \mathrm{~B}+b_{3} \mathrm{C}+b_{4} \mathrm{D}+b_{12} \mathrm{AB}+b_{13} \mathrm{AC} \\
& +b_{23} \mathrm{BC}+b_{24} \mathrm{BD}+b_{11} \mathrm{~A}^{2}+b_{22} \mathrm{~B}^{2}+\mathrm{b}_{33} \mathrm{C}^{2} \\
& +\mathrm{b}_{44} \mathrm{D}^{2}
\end{aligned}
$$

In this equation, $Y$ is the predicted response in terms of xylanase activity. In this study, the Box-Behnken design consisted of four factors viz. incubation time (A) $[12,36$, and $60 \mathrm{~h}], \mathrm{pH}(\mathrm{B})[6,7.5$, and 9.0], substrate concentration $(\mathrm{C})[0.5,1,1.5(\%)]$, and temperature (D) [35, 42.5 , and $\left.50\left({ }^{\circ} \mathrm{C}\right)\right]$ further production of xylanase enzyme from SXB19 strain of xylanolytic bacteria. $b_{0}$ is the inter shape or offset term taken from the equation; $b_{1}, b_{2}, b_{3}$, and $b_{4}$ are the linear effect; and $b_{11}, b_{22}, b_{33}$, and $b_{44}$ are quadratic terms. Further, the RSM data were undertaken

Table 1 Actual levels for the four variables Box-Behnken design in response surface methodology of the xylanase enzyme extracted from the bacterium Pseudomonas mohnii

\begin{tabular}{lllll}
\hline Independent variables & symbols & \multicolumn{3}{l}{ Coded and actual levels } \\
\cline { 3 - 5 } & & $\mathbf{- 1}$ (low) & $\mathbf{0}$ & $\mathbf{+ 1 \text { (high) }}$ \\
\hline Incubation time (h) & $\mathrm{A}$ & 12 & 36 & 60 \\
$\mathbf{p H}$ & $\mathrm{B}$ & 6.0 & 7.5 & 9.0 \\
Xylan concentration (\%) & $\mathrm{C}$ & 0.5 & 1 & 1.5 \\
Temperature $\left({ }^{\circ} \mathrm{C}\right)$ & $\mathrm{D}$ & 35.0 & 42.5 & 50.0 \\
\hline
\end{tabular}

for regression analysis and analysis of variance (ANOVA) to fit the model according to abovementioned equation. Adequacies of the resulted model were validated by regression analysis and $R^{2}$ analysis. $F$ value was verified to determine the statistical probability of all calculated models at a $5 \%$ level of significance $[33,34]$. To understand the relationship between predicted response and experimental level of each factor and to explore the optimum xylanase production condition, the fitted equation was expressed as optimized three-dimensional surface plots, which is also prepared using the software Design-Expert.

\section{Culture of bacteria according to the experimental condition designed by RSM}

For the bacterial culture, growth media containing (g/ $100 \mathrm{ml}) 1.7 \mathrm{~g}$ tryptone, $0.3 \mathrm{~g}$ peptone, $0.25 \mathrm{~g} \mathrm{~K} \mathrm{HPO}_{4}$, and $1.8 \mathrm{~g} \mathrm{NaCl}$ were prepared and the $\mathrm{pH}$ of the media adjusted to three different values (6.0, 7.5, and 9) according to the conditions designed by RSM. The growth media were supplemented with different concentrations of xylan $(0.5,1$, and $1.5 \%)$ as mentioned in the experimental design. All the flasks containing culture broth were autoclaved at $121{ }^{\circ} \mathrm{C}$ for $15 \mathrm{~min}$. After autoclave, the flasks were set to cool at room temperature and placed under UV laminar flow for sterilization. After few minutes, each flask was inoculated with $1 \%$ of standard inoculum (v/v) of the SXB19 xylanolytic bacterial strain which was freshly cultivated for $24 \mathrm{~h}$. The inoculated flask was then incubated on a rotary shaker $(120 \mathrm{rpm})$ at a specific temperature $\left(35,42.5,50^{\circ} \mathrm{C}\right)$ and for a specific time $(12,36,60 \mathrm{~h})$ as given in the experimental design from the RSM calculation.

\section{Estimation of xylanase production}

After the incubation according to the designed experimental conditions, $1 \mathrm{ml}$ of bacterial culture from each flask was taken in the Eppendorf tube. In this study, xylanase activity was measured in duplicate by preparing two Eppendorf tubes containing bacterial culture for each experimental condition. Each Eppendorf tube containing $1 \mathrm{ml}$ bacterial culture broth was centrifuged at $10,000 \mathrm{rpm}$ for $10 \mathrm{~min}$ at $4{ }^{\circ} \mathrm{C}$. After centrifugation, the bacterial supernatants were collected to perform the DNS assay for the determination of xylanase activity [26]. The predicated values of xylanase activity obtained from each experimental condition were then used to generate three-dimensional surface plots, regression analysis, and analysis of variance (ANOVA).

\section{Results}

Isolation and screening of xylanolytic bacteria

A total of 19 xylanolytic bacteria were isolated from soil samples from Simlipal Biosphere Reserve, Odisha, using 
Table 2 Xylan degrading activity of different isolated bacterial strains based on the measurement of xylan hydrolyzing zone

\begin{tabular}{|c|c|c|c|c|c|c|}
\hline SI No. & Isolate name & $\begin{array}{l}\text { Halo's diameter } \\
\text { horizontally X(in cm) }\end{array}$ & $\begin{array}{l}\text { Halo's diameter } \\
\text { vertically } Y(\text { in } \mathrm{cm})\end{array}$ & $\begin{array}{l}\text { Average halo's diameter }[\mathrm{H}] \\
=(\mathrm{X}+\mathrm{Y}) / 2(\mathrm{in} \mathrm{cm})\end{array}$ & Colony diameter $[\mathrm{C}]$ & $\mathrm{H}: \mathrm{C}$ \\
\hline 1 & SXB1 & 0.7 & 0.5 & 0.6 & 0.567 & 1.06 \\
\hline 2 & SXB2 & 1 & 1 & 1 & 0.567 & 1.76 \\
\hline 3 & SXB3 & 1.1 & 1.1 & 1.1 & 0.567 & 1.94 \\
\hline 4 & SXB4 & 1 & 1.1 & 1.05 & 0.567 & 1.85 \\
\hline 5 & SXB5 & 0.9 & 0.8 & 0.85 & 0.567 & 1.49 \\
\hline 6 & SXB6 & 1.39 & 1.29 & 1.34 & 0.567 & 2.36 \\
\hline 7 & SXB7 & 1.1 & 1.6 & 1.35 & 0.567 & 2.38 \\
\hline 8 & SXB8 & 1.39 & 1.2 & 1.295 & 0.567 & 2.28 \\
\hline 9 & SXB9 & 2 & 2.2 & 2.1 & 0.567 & 3.70 \\
\hline 10 & SXB10 & 2 & 2 & 2 & 0.567 & 3.53 \\
\hline 11 & SXB11 & 1.95 & 2.1 & 2.025 & 0.567 & 3.57 \\
\hline 12 & SXB12 & 2.12 & 2.13 & 2.125 & 0.567 & 3.75 \\
\hline 13 & SXB13 & 2.1 & 2 & 2.05 & 0.567 & 3.61 \\
\hline 14 & SXB14 & 2.14 & 2.12 & 2.13 & 0.567 & 3.76 \\
\hline 15 & SXB15 & 1.9 & 1.8 & 1.85 & 0.567 & 3.26 \\
\hline 16 & SXB16 & 2.2 & 2.2 & 2.2 & 0.567 & 3.88 \\
\hline 17 & SXB17 & 1.9 & 1.7 & 1.8 & 0.567 & 3.17 \\
\hline 18 & SXB18 & 2.3 & 2.45 & 2.375 & 0.567 & 4.19 \\
\hline 19 & SXB19 & 2.5 & 2.5 & 2.5 & 0.567 & 4.40 \\
\hline
\end{tabular}

a xylan-rich medium and designated as Simlipal xylanolytic bacteria (SXB1-SXB19). These bacteria were purified by subsequent sub-culturing and used for further experiments. Comparative xylan-hydrolyzing zone has been determined for all the isolated bacteria. The range of the average diameter of xylan-degrading halo size $(H)$ observed for all the strains was between 0.6 and $2.5 \mathrm{~cm}$ (Table 2). Among the different bacterial isolates, SXB19 showed a comparatively higher halozone formation in xylan-enriched nutrient agar plate. The strain SXB19 exhibited the most prominent yellow patch surrounding its growth among all the xylan-degrading bacteria with a halozone size of 2.5 $\mathrm{cm}$ implicating the most efficient xylan-degrading bacterial strain (Fig. 1). The average colony diameter (C) for all the bacterial isolates was the same with a value of $0.567 \mathrm{~cm}$. After comparing the ratio of the halo's diameter and colony diameter $(H: C)$, it was also found that the strain SXB19 has the highest $H: C$ value of $4.40 \mathrm{~cm}$ among all.

\section{Determination of bacterial xylanase activity}

The result of bacterial xylanase activity determination is given in Fig. 2. In accordance with the qualitative estimation performed during screening, the bacterial isolate SXB19 showed the highest xylanase activity as measured in the DNS method. The obtained high spectrometric absorbance values indicated the formation of maximum amount of reducing sugar after the catalytic activity of xylanase on the substrate xylan. According to the obtained result, xylanase activity of the bacterial strain SXB19 was recorded to have the highest enzymatic activity of $22.5 \mathrm{IU} / \mathrm{ml}$ after a 24 -h incubation time.

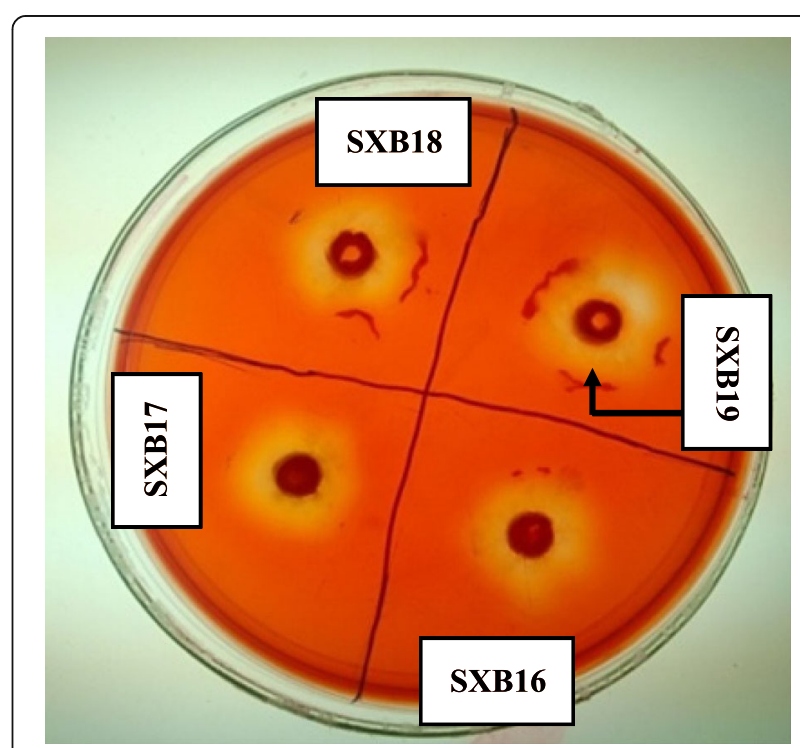

Fig. 1 Clearing zone generated by xylanolytic bacteria SXB19 in xylan agar plates after Congo red staining 


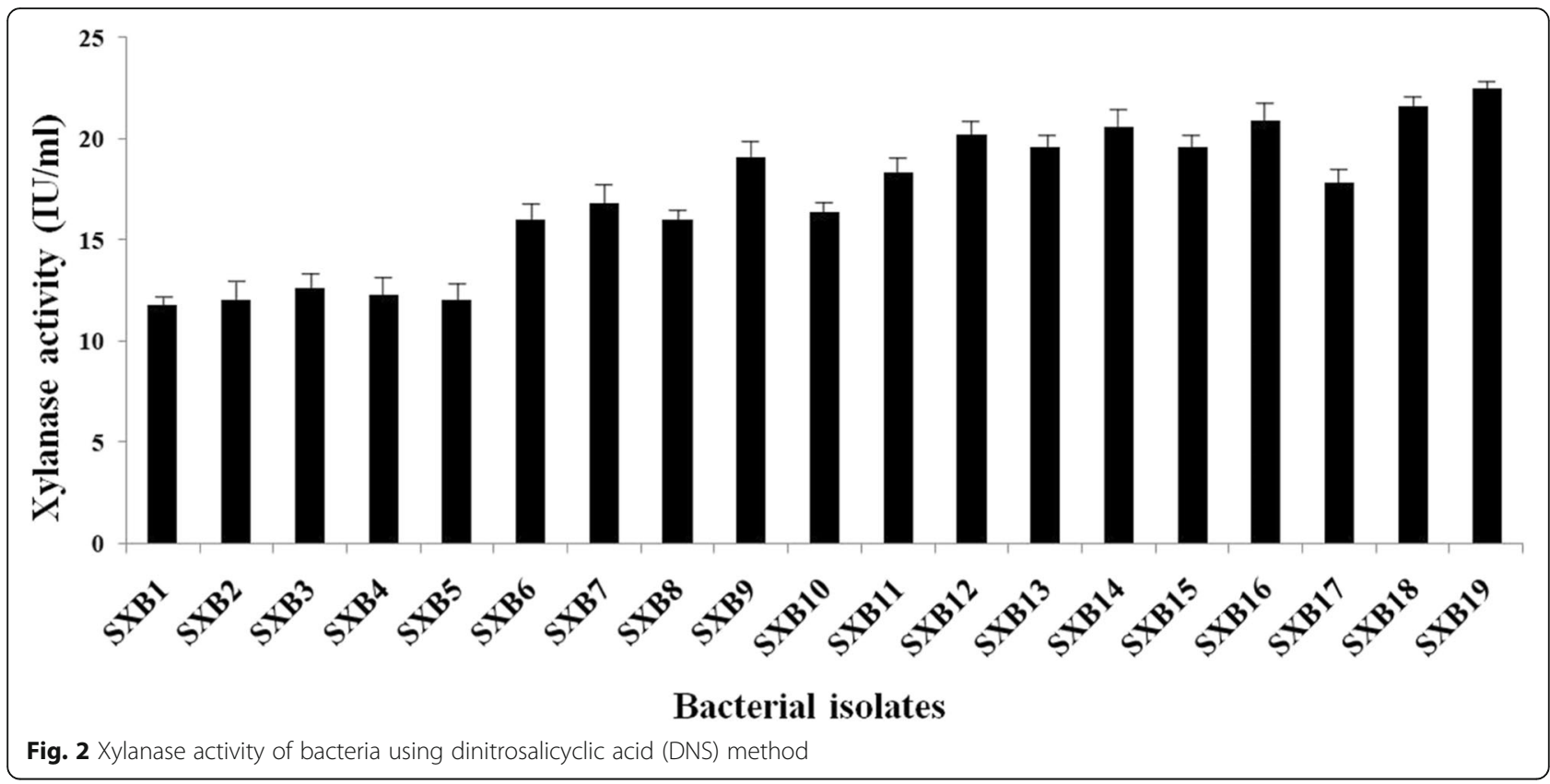

\section{Growth curve analysis}

Figure 3 shows the growth profile of bacterial isolate SXB19 along with its xylanase activity in xylan-enriched nutrient broth. The lag phase of the bacterium was recorded up to the first $2 \mathrm{~h}$ after the inoculation. It is found from the experiment that the exponential phase of xylanolytic bacteria SXB19 started after $2 \mathrm{~h}$ which extends up to $22 \mathrm{~h}$. Thereafter, the growth of the bacteria enters into the stationary phase. The average absorbance value of bacterial growth for SXB19 at its stationary phase was recorded 2.182 , and the maximum values reached 2.193 in $26 \mathrm{~h}$ of incubation. Xylanase activity of SXB19 culture supernatant was detected after $2 \mathrm{~h}$ of the bacterial growth started. SXB19 showed a gradual increase in xylanase activity between 4 and $18 \mathrm{~h}$ of its exponential growth phase with a value of 5.39 to $13.62 \mathrm{IU} /$ $\mathrm{ml}$. Further, in the present study, during 20 to $28 \mathrm{~h}$ of SXB19 growth, the enzymatic activity increased rapidly with a value of 16.13 to $30 \mathrm{IU} / \mathrm{ml}$. Xylanase activity of SXB19 remained more or less constant within the time period from 30 to $36 \mathrm{~h}$. The highest xylanase activity of $31.7 \mathrm{IU} / \mathrm{ml}$ was observed at $36 \mathrm{~h}$. In the dye off phase of

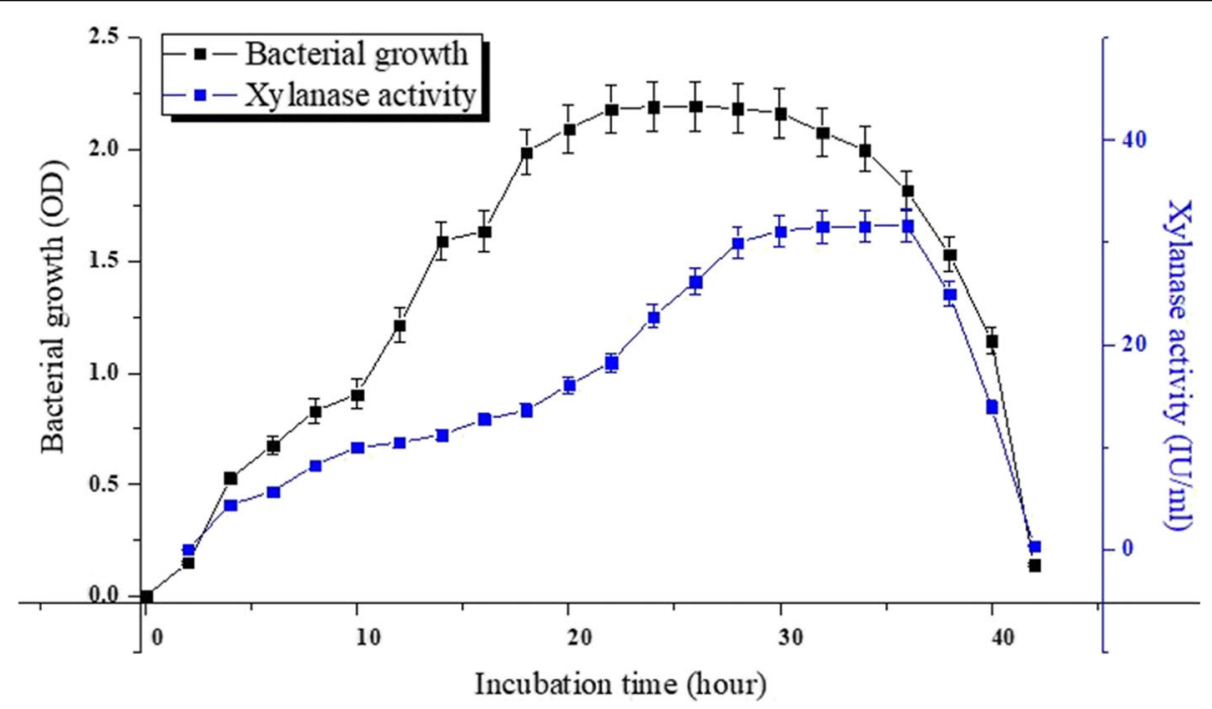

Fig. 3 Bacterial growth curve and xylanase activity of isolated xylanolytic bacteria SXB19. The bacterium was cultured in a xylan-enriched nutrient broth medium containing $0.5 \%$ of corn cob xylan and was incubated at $37^{\circ} \mathrm{C}$ 
the bacterial strain, the absorbance value suddenly dropped from 2.0 at $34 \mathrm{~h}$ to 1.53 at $38 \mathrm{~h}$ which finally reached to 0.142 at the end of $42 \mathrm{~h}$. Xylanase activity is also reported to be significantly dropped down from 25 to $0.36 \mathrm{IU} / \mathrm{ml}$ during the time period of the dye off phase.

\section{Morphological and biochemical characterization of xylanolytic bacteria}

For morphological characterization, the xylanolytic strain SXB19 was studied for its shape and the pattern of gram staining. The strain SXB19 was found to be a rod-shaped Gram-negative bacterium. Further biochemical characterizations were also performed to identify the xylanolytic bacterial isolate SXB19. The results of biochemical tests are presented in Table 3. In the catalase test, a positive result is indicated by the production of bubbles in the form of oxygen in the nutrient agar plates. The xylanolytic bacterial strain SXB19 showed a negative result towards the catalase test. In the oxidase test, the xylanolytic train SXB19 showed a positive reaction indicated by a change in color of the broth to colorless within few seconds. In the urease test, a positive result was indicated by the pinkish-red coloration of the medium after the inoculation with SXB19 strain. In the methyl red test, the SXB19 strain showed a positive result indicated by the change of color of the growth medium to red. The SXB19 strain showed a positive result in the Voges-Proskauer test indicated by the development of a crimson yellow color of the medium. In the citrate utilization test, the growth of SXB19 xylanolytic strain on the slants accompanied by a change of color of

Table 3 Morphological and biochemical characterization of SXB19 xylanolytic bacterial isolate

\begin{tabular}{ll}
\hline Morphological character & Pattern \\
Shape of the bacterial cell & Rod \\
Gram staining & Negative \\
Biochemical tests & - \\
Catalase & + \\
Oxidase & + \\
Urease & + \\
Methyl red (MR) & + \\
Voges Proskauer (VP) & + \\
Citrate utilization & + \\
Carbohydrate metabolism & + \\
Oxidative/Fermentative & Oxidative \\
Indole & - \\
$\mathrm{H}_{2} \mathrm{~S}$ & - \\
Gelatin hydrolysis & - \\
Coagulase & - \\
\hline
\end{tabular}

slants to blue indicates a positive result. In the carbohydrate metabolism test, a positive result by SXB19 strain is indicated by the change of the color of the broth to a yellow color along with gas production. The oxidativefermentative test determined that the SXB19 bacterial strain was oxidative. The bacterial strain showed negative results for the indole, $\mathrm{H}_{2} \mathrm{~S}$, and coagulase tests. According to the observation from gelatin hydrolysis, this bacteria was shown to have a negative result towards this test. Based on these abovementioned characteristics observed from the morphological and biochemical tests and references from Bergey's Manual of Systematic Bacteriology, the xylanolytic bacterial isolate SXB19 was tentatively identified as a member of the genus Pseudomonas.

\section{Molecular identification of xylanolytic bacterial strain SXB19}

In the $16 \mathrm{~S}$ rRNA gene sequencing, a molecular approach was undertaken to identify the bacterium at its species level. The forward and reverse partial sequences of SXB19 xylanolytic bacterial isolate obtained from $16 \mathrm{~S}$ rRNA gene sequencing are shown to retain a length of 882 and 856 bp, respectively (Fig. S1 and Fig. S2).

\section{Phylogenetic tree analysis of xylanolytic bacterial strain SXB19}

The neighbor-joining method was performed to construct the phylogenetic tree using the 16SrRNA sequence data of SXB19 for the identification of the bacterium. Based on the results from the phylogenetic tree analysis, it can be observed that the 16S rRNA gene sequence alignment of isolate SXB19 is very closely related to Pseudomonas mohnii HB B 7087 with the highest similarity index of 99\% under the CLADE-III (Fig. 4). Therefore, on the basis of 16S rRNA gene sequencing and phylogeny analysis, the SXB19 strain was identified as Pseudomonas mohnii.

\section{Optimization of xylanolytic enzyme activity}

Different inorganic nutrients like carbon, nitrogen, and metal sources are indispensable for the optimum growth of bacteria and its enzyme activity. Hence, experiments were conducted to evaluate the effect of carbon, nitrogen, and metal ions on xylanase activity of Pseudomonas mohnii. Further, optimization of different parameters like $\mathrm{pH}$, temperature, incubation time, and substrate concentration to maximize the xylanase activity of the bacterium $P$. mohnii was also performed using the response surface method.

\section{Effect of carbon sources on xylanase activity}

The effect of different carbon sources on xylanase activity along with xylan was performed in the same basal media and culture conditions. When xylan was replaced 


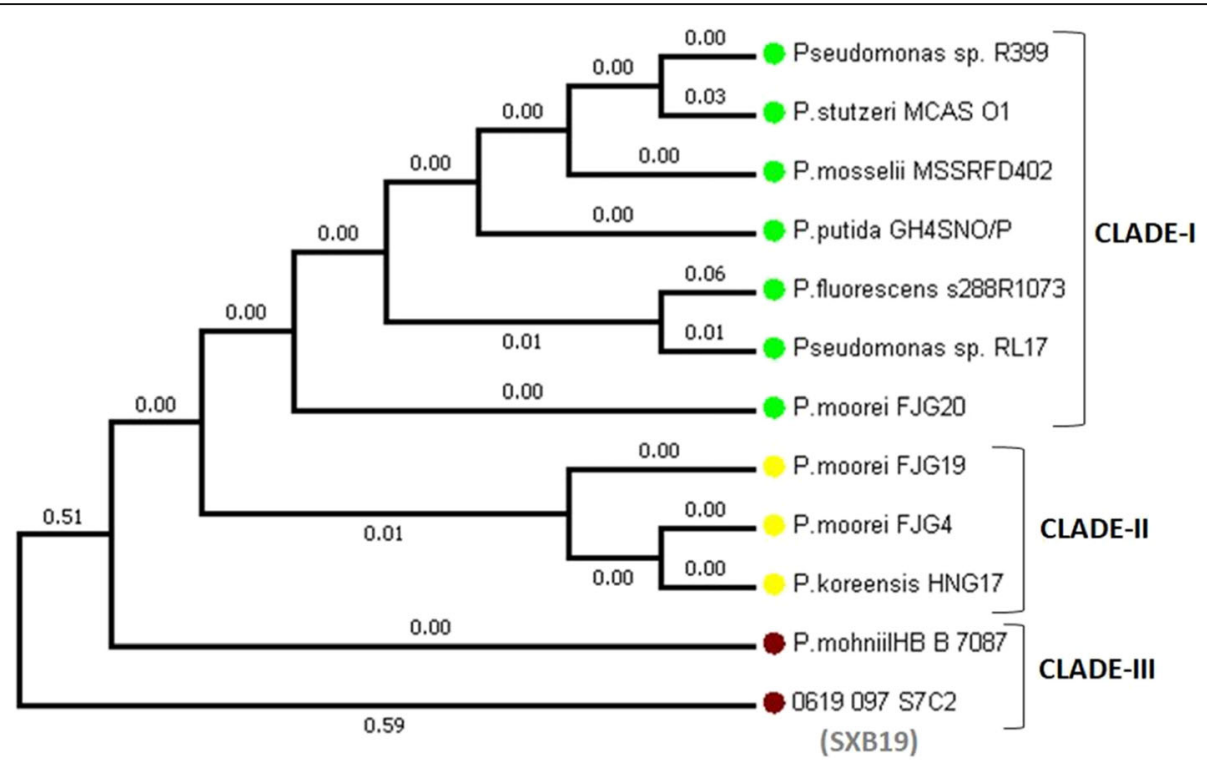

Fig. 4 Phylogenetic tree for the bacterial isolate SXB19

with different carbon sources, viz. glucose, fructose, sucrose, and starch in the growth medium of the bacterium Pseudomonas mohnii, maximum xylanase-specific activity was recorded with xylan $(22.5 \mathrm{IU} / \mathrm{ml}$ as calculated from enzyme determination), followed by starch $(8.4 \mathrm{IU} / \mathrm{ml})$, glucose $(3.04 \mathrm{IU} / \mathrm{ml})$, sucrose $(2.5 \mathrm{IU} / \mathrm{ml})$, and fructose $(1.71 \mathrm{IU} / \mathrm{ml})$ (Fig. 5). This result depicted that xylan compared to other carbon sources strongly induce xylanase production. A notable reduced activity was observed in the case of glucose, fructose, and sucrose, which may be resulted from the fact that easily metabolizable substrates inhibit the enzyme activity.

\section{Effect of nitrogen sources on xylanase activity}

Enzyme activity is also significantly regulated by one of the major factors which is a different nitrogen source.

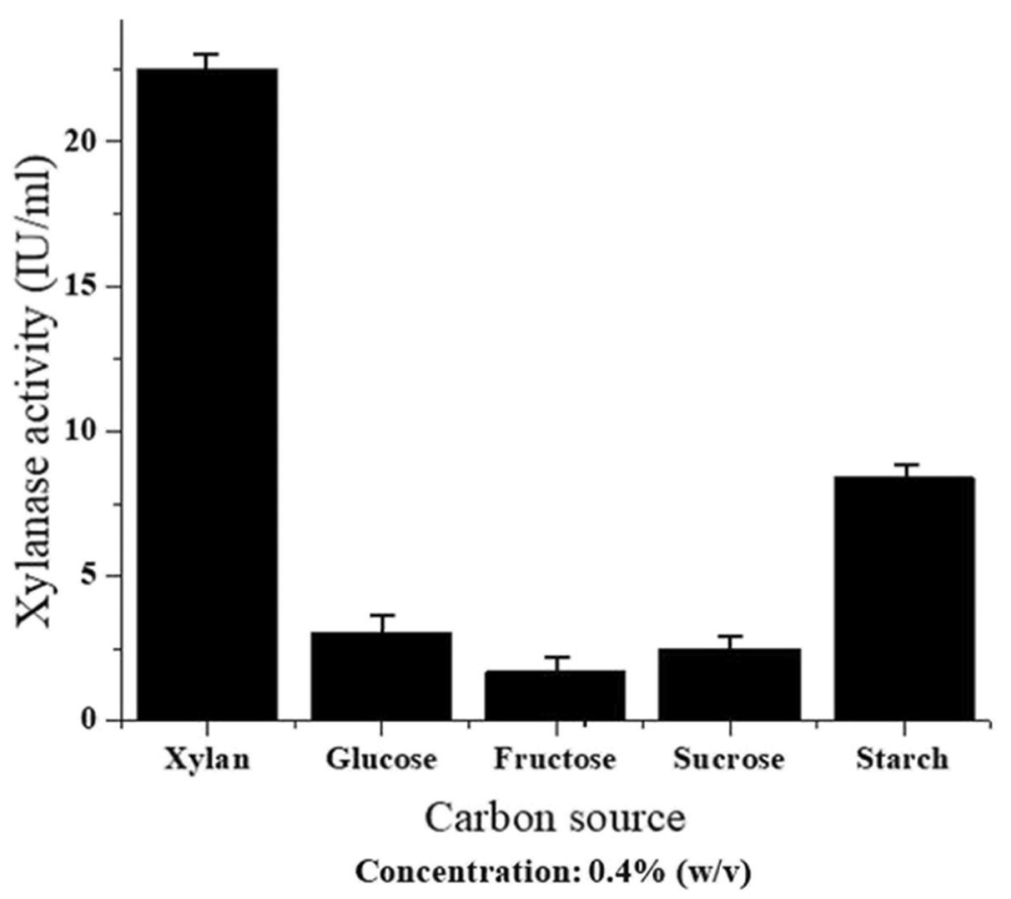

Fig. 5 Effect of different carbon sources on xylanase activity of the bacterium Pseudomonas mohnii 
Maximum xylanase activity of $21.72 \mathrm{IU} / \mathrm{ml}$ for the strain of Pseudomonas mohnii was obtained with the growth medium supplied with $0.4 \%$ urea (Fig. 6). The second highest xylanase activity with a value of $19.39 \mathrm{IU} / \mathrm{ml}$ was observed for yeast extract followed by other three nitrogen sources viz. $\mathrm{NH}_{4} \mathrm{NO}_{3}(18.42 \mathrm{IU} / \mathrm{ml}), \mathrm{NaNO}_{3}(18.09$ $\mathrm{IU} / \mathrm{ml})$, and peptone (16.49 IU/ml) (Fig. 6).

\section{Effect of metal ion sources on xylanase activity}

Xylanase activity was shown to greatly influenced by the metal ion source. The addition of metal ion sources such as $\mathrm{MnSO}_{4}$ and $\mathrm{CuSO}_{4}$ in the growth medium of Pseudomonas mohnii showed a significant decrease in the enzyme activity with a value of $2.71 \mathrm{IU} / \mathrm{ml}$ and $4.66 \mathrm{IU} / \mathrm{ml}$, respectively (Fig. 7). Other selected metal ion sources viz. $\mathrm{CaCl}_{2}, \mathrm{CoCl}_{2}, \mathrm{MgSO}_{4}, \mathrm{ZnSO}_{4}$, and $\mathrm{FeSO}_{4}$ had not such notable impact on xylanase activity, while a slight stimulatory effect of the chemical additive $\mathrm{KCl}$ on xylanase activity $(20.35 \mathrm{IU} / \mathrm{ml})$ of Pseudomonas mohnii was observed (Fig. 7).

\section{Optimization of growth factors through response surface methodology}

In this study, RSM was used to determine the xylanase activity for bacterial strain Pseudomonas mohnii in different growth factors. There are four independent variables such as incubation time, $\mathrm{pH}$, substrate conc., and temperature based on which the responses were calculated. The full experimental plan as per the designed parameters along with the response values are given in Table 4.

\section{Regression analysis}

A regression analysis was performed to determine the optimum conditions that result in the maximum xylanase activity. Using multiple regression analyses, a second-order polynomial equation was developed which represents the relationship between enzyme activity, incubation time, $\mathrm{pH}$, substrate concentration, and temperature. The fitted response of the model is calculated as follows:

$$
\begin{aligned}
\text { Xylanase activity }(Y)= & +55.57+7.66 \times \mathrm{A}+6.12 \\
& \times \mathrm{B}-11.88 \times \mathrm{C}-11.40 \times \mathrm{D} \\
& +17.62 \times \mathrm{AB}-21.60 \\
& \times \mathrm{AC}-11.40 \times \mathrm{AD}+41.00 \\
& \times \mathrm{BC}-14.82 \times \mathrm{BD}+7.23 \\
& \times \mathrm{CD}+11.36 \times \mathrm{A}^{2}+32.25 \\
& \times \mathrm{B}^{2}+18.02 \times \mathrm{C}^{2}-0.7475 \\
& \times \mathrm{D}^{2}
\end{aligned}
$$

In the above equation, $Y$ is the response value of xylanase activity. Incubation time, $\mathrm{pH}$, substrate concentration, and temperature were represented by $\mathrm{A}$, $\mathrm{B}, \mathrm{C}$, and D, respectively. The significance of the second-order polynomial equation for xylanase activity was measured by the analysis of variance (ANOVA). The coded equation assists to determine the relative impact of the factors by analyzing the factor coefficient. The polynomial equation implied that for the expression of xylanase activity, the parameters like $\mathrm{A}$, $\mathrm{B}, \mathrm{C}, \mathrm{D}, \mathrm{AB}, \mathrm{AC}, \mathrm{AD}, \mathrm{BC}, \mathrm{BD}, \mathrm{CD}, \mathrm{A}^{2}, \mathrm{~B}^{2}$, and $\mathrm{C}^{2}$ are the most significant terms of the experimental model. The coefficient of variation $(\mathrm{CV})$ denotes the degree of precision with which the experimental

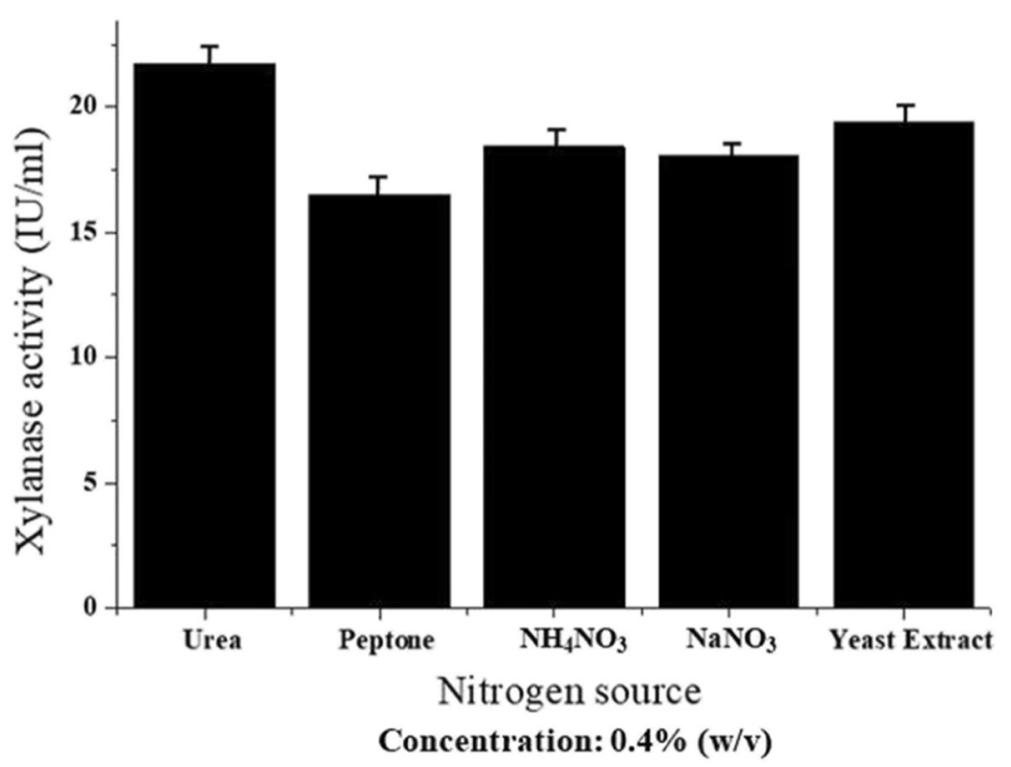

Fig. 6 Effect of different nitrogen sources on xylanase activity of the bacterium Pseudomonas mohnii 


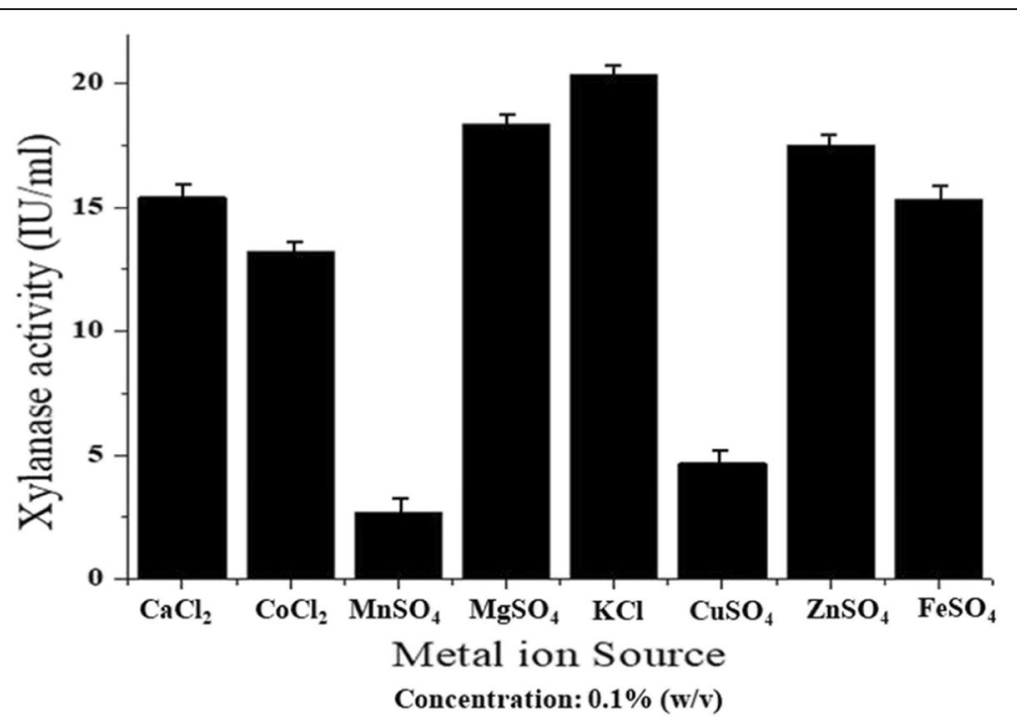

Fig. 7 Effect of different metal ion sources on xylanase activity of the bacterium Pseudomonas mohnii

conditions are compared. In the present study, a CV value of $3.22 \%$ has been recorded for the RSM model of xylanase activity for Pseudomonas mohnii. Calculated $p$ value as obtained from the coefficient table was recorded as $<0.0001$ which signifies the major impact of $\mathrm{A}, \mathrm{B}, \mathrm{C}, \mathrm{D}, \mathrm{AB}, \mathrm{AC}, \mathrm{AD}, \mathrm{BC}, \mathrm{BD}, \mathrm{CD}, \mathrm{A}^{2}$,
$\mathrm{B}^{2}$, and $\mathrm{C}^{2}$ towards the highest coefficient value for xylanase activity.

\section{Statistical analysis}

To check the statistical significance of the quadratic model developed for xylanase activity of Pseudomonas

Table 4 Optimization of fermentation parameters using response surface methodology with Box-Behnken design

\begin{tabular}{|c|c|c|c|c|c|c|}
\hline SL. No. & Incubation (h) & $\mathrm{pH}$ & Xylan Conc. (\%) & Temperature $\left({ }^{\circ} \mathrm{C}\right)$ & Xylanase activity Experimental (IU/ml) & Xylanase activity Predicted (IU/ml) \\
\hline 1. & 36 & 6.0 & 1 & 50.0 & 83.70 & 84.38 \\
\hline 2. & 36 & 9.0 & 1.5 & 35.0 & 149.90 & 145.08 \\
\hline 3. & 36 & 6.0 & 1.5 & 35.0 & 25.10 & 26.85 \\
\hline 4. & 60 & 7.5 & 1 & 50.0 & 48.70 & 51.04 \\
\hline 5. & 36 & 7.5 & 1.5 & 35.0 & 63.20 & 63.2 \\
\hline 6. & 60 & 7.5 & 1.5 & 50.0 & 52.60 & 55.57 \\
\hline 7. & 12 & 6.0 & 1 & 42.5 & 104.30 & 103.03 \\
\hline 8. & 12 & 7.5 & 0.5 & 42.5 & 65.70 & 67.56 \\
\hline 9. & 60 & 6.0 & 1 & 42.5 & 84.00 & 83.10 \\
\hline 10. & 60 & 7.5 & 0.5 & 50.0 & 148.90 & 146.09 \\
\hline 11. & 36 & 7.5 & 1 & 42.5 & 54.20 & 55.57 \\
\hline 12. & 60 & 7.5 & 0.5 & 42.5 & 147.8 & 146.08 \\
\hline 13. & 60 & 9.0 & 1 & 35.0 & 149.00 & 149.41 \\
\hline 14. & 60 & 7.5 & 1 & 35.0 & 97.80 & 96.65 \\
\hline 15. & 12 & 7.5 & 1 & 35.0 & 60.08 & 58.52 \\
\hline 16. & 36 & 9.0 & 1 & 50.0 & 68.00 & 66.97 \\
\hline 17. & 36 & 6.0 & 1 & 35.0 & 75.40 & 77.53 \\
\hline 18. & 36 & 7.5 & 0.5 & 35.0 & 105.10 & 103.34 \\
\hline 19. & 12 & 9.0 & 1 & 42.5 & 81.00 & 80.02 \\
\hline 20. & 60 & 9.0 & 1.5 & 42.5 & 141.20 & 140.59 \\
\hline 21. & 12 & 7.5 & 1 & 50.0 & 56.60 & 58.53 \\
\hline 22. & 36 & 7.5 & 0.5 & 35.0 & 59.90 & 59.13 \\
\hline 23. & 12 & 7.5 & 1.5 & 42.5 & 87.00 & 87.01 \\
\hline 24. & 36 & 7.5 & 1.5 & 50.0 & 56.90 & 56.79 \\
\hline 25. & 12 & 9.0 & 0.5 & 42.5 & 40.80 & 42.83 \\
\hline 26. & 36 & 6.0 & 0.5 & 42.5 & 152.00 & 152.60 \\
\hline 27 & 36 & 7.5 & 1 & 42.5 & 54.20 & 55.57 \\
\hline
\end{tabular}


mohnii, RSM was used to perform the $F$ test and the analysis of variance (ANOVA). It has been shown from the obtained result that the model was highly significant, as suggested by the calculated $F$ value (230.17) and low probability value $(<0.0001)$. The lack of fit $F$ value of 0.3782 indicates that this value is not significant to the pure error. There is an $88.03 \%$ chance that a lack of fit $F$ value goes larger due to noise (Table 5). This nonsignificant lack of fit as represented from the ANOVA table evidence the optimization of the model system. The coefficient of determination $\left(R^{2}\right)$ was calculated as 0.9963 for enhanced xylanase activity, representing that the statistical model can explain the adequate variability in the response. Similarly, The predicted $R^{2}$ value of 0.9831 was in well agreement with the adjusted $R^{2}$ value of 0.9920 . This represents a good coherence between the experimental and predicted values for xylanase activity. If there are many terms in the model and the sample size is not very large, the adjusted $R^{2}$ value may be noticeably smaller than the $R^{2}$. In the present study, in concur with the above statement, adjusted $R^{2} 0.9920$ is also less than the $R^{2}$ value 0.9963 (Table 6).

\section{Interaction among variables}

The effects of interactions among the variables on xylanase activity were studied. Interactive effects of any two variables were represented by optimized 3D surface plots while keeping the other variable fixed at the point values of different levels.

The response surface curves represented how xylanase production was a function of $\mathrm{pH}$ and incubation time by keeping the levels of temperature and substrate conc. constant at $35^{\circ} \mathrm{C}$ and $1.5 \%$, respectively. The increase in $\mathrm{pH}$ in the same time resulted in the elevation of xylanase activity from 25.10 to $149.9 \mathrm{IU} / \mathrm{ml}$ (Fig. 8a). The response surface plots represented in Fig. 8b show that there was a high production of xylanase $(141.2 \mathrm{IU} / \mathrm{ml})$ at substrate conc. $1.5 \%$ and incubation time $60 \mathrm{~h}$ and low yields $(40.8 \mathrm{IU} / \mathrm{ml})$ at substrate conc. 0.5 and incubation time $12 \mathrm{~h}$ with constant temperature and $\mathrm{pH}$. Figure $8 \mathrm{c}$ presents the response surface curves which revealed how xylanase production was a function of temperature and incubation time by keeping the levels of $\mathrm{pH}$ and substrate conc. constant at 7.5 and $0.5 \%$, respectively. The increase in incubation time and temperature resulted in an increment of xylanase activity from 59.9 to 147.8 IU/ $\mathrm{ml}$. The response surface curves as presented in Fig. 8d depict how xylanase production was a function of substrate conc. and $\mathrm{pH}$ by keeping the levels of temperature and incubation time constant at $42.5{ }^{\circ} \mathrm{C}$ and $36 \mathrm{~h}$, respectively. In this condition, an increase in substrate conc. resulted in an increase of xylanase activity from 48.10 to $152 \mathrm{IU} / \mathrm{ml}$. The response surface curves depicted in Fig. 8e show that there was high production of xylanase $(149 \mathrm{IU} / \mathrm{ml})$ at temperature $35^{\circ} \mathrm{C}$ and $\mathrm{pH} 9.0$

Table 5 Analysis of variance (ANOVA) for the quadratic model of xylanase enzyme activity as per Box-Behnken design

\begin{tabular}{|c|c|c|c|c|c|}
\hline Source & Sum of Squares & Degree of freedom & Mean Square & F-value & $p$-value \\
\hline Model & $22,859.79$ & 14 & 1632.84 & 230.17 & $<0.0001$ \\
\hline A-Incubation time & 704.11 & 1 & 704.11 & 99.25 & $<0.0001$ \\
\hline B-pH & 448.96 & 1 & 448.96 & 63.29 & $<0.0001$ \\
\hline C-Substrate Conc. & 1692.19 & 1 & 1692.19 & 238.53 & $<0.0001$ \\
\hline D-Temperature & 1559.06 & 1 & 1559.06 & 219.77 & $<0.0001$ \\
\hline$A B$ & 1242.56 & 1 & 1242.56 & 175.15 & $<0.0001$ \\
\hline$A C$ & 1866.24 & 1 & 1866.24 & 263.07 & $<0.0001$ \\
\hline$A D$ & 520.30 & 1 & 520.30 & 73.34 & $<0.0001$ \\
\hline$B C$ & 6724.00 & 1 & 6724.00 & 947.82 & $<0.0001$ \\
\hline $\mathrm{BD}$ & 879.12 & 1 & 879.12 & 123.92 & $<0.0001$ \\
\hline$C D$ & 208.80 & 1 & 208.80 & 29.43 & 0.0002 \\
\hline$A^{2}$ & 688.87 & 1 & 688.87 & 97.10 & $<0.0001$ \\
\hline$B^{2}$ & 5548.72 & 1 & 5548.72 & 782.15 & $<0.0001$ \\
\hline$C^{2}$ & 1731.36 & 1 & 1731.36 & 244.05 & $<0.0001$ \\
\hline$D^{2}$ & 2.98 & 1 & 2.98 & 0.4201 & 0.5291 \\
\hline Residual & 85.13 & 12 & 7.09 & & \\
\hline Lack of fit & 55.68 & 10 & 5.57 & 0.3782 & 0.8803 \\
\hline Pure Error & 29.45 & 2 & 14.72 & & \\
\hline Cor Total & $22,944.92$ & 26 & & & \\
\hline
\end{tabular}


Table 6 Fit statistics of the response model for xylanase activity of Pseudomonas mohnii calculated by response surface methodology

\begin{tabular}{llllll}
\hline $\mathbf{R}^{\mathbf{2}}$ & Adjusted $\mathbf{R}^{\mathbf{2}}$ & Predicted $\mathbf{R}^{\mathbf{2}}$ & Adeq Precision & C.V. \% & Standard deviation \\
\hline 0.9963 & 0.9920 & 0.9831 & 53.2680 & 3.22 & 2.66 \\
\hline
\end{tabular}

but low yields $(52.60 \mathrm{IU} / \mathrm{ml})$ at a higher temperature of $50^{\circ} \mathrm{C}$ and a lower $\mathrm{pH}$ of 7.5 while other two variables substrate conc. and incubation time were kept fixed at $1 \%$ and $60 \mathrm{~h}$, respectively. Figure $8 \mathrm{f}$ represents the response surface curves which depicted how xylanase production was a function of substrate conc. and temperature by keeping the levels of incubation time and $\mathrm{pH}$ constant at $36 \mathrm{~h}$ and 6 , respectively. In this condition, the result showed that a decrease in substrate conc. from 1.5 to $0.5 \%$ resulted in promoting the

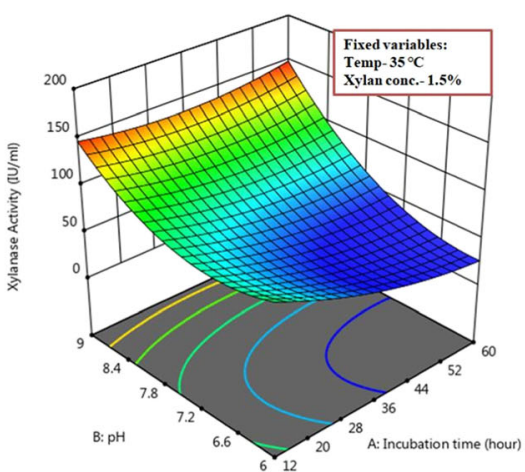

A
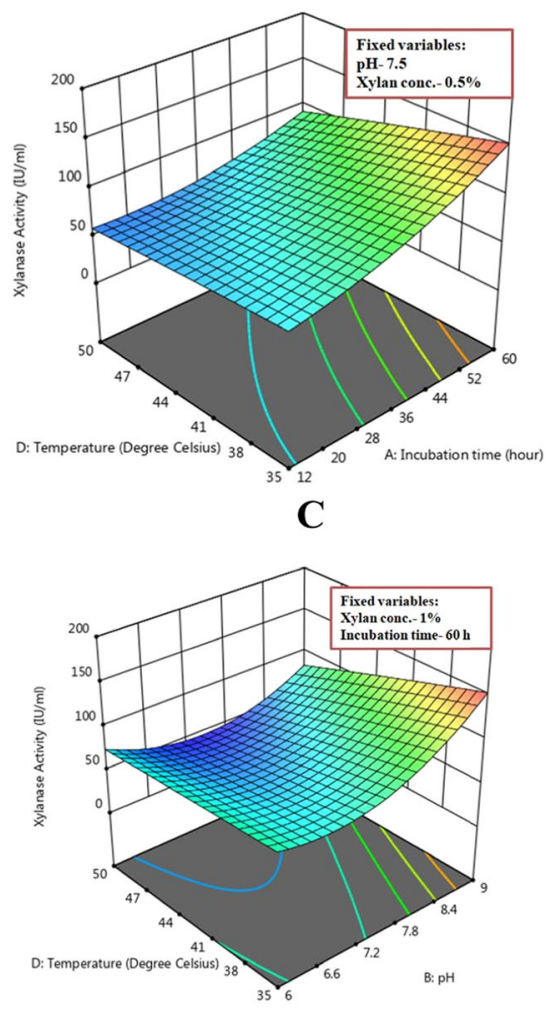

$\mathbf{E}$

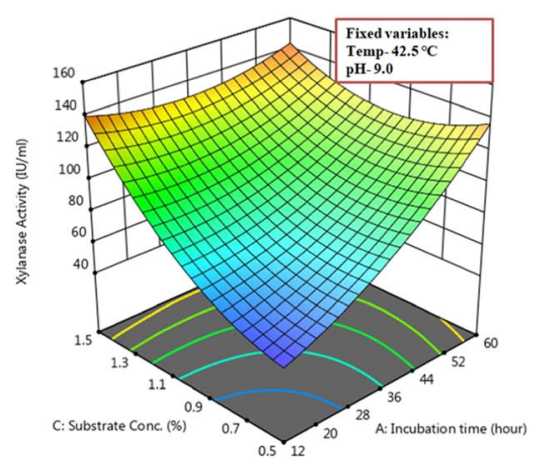

B

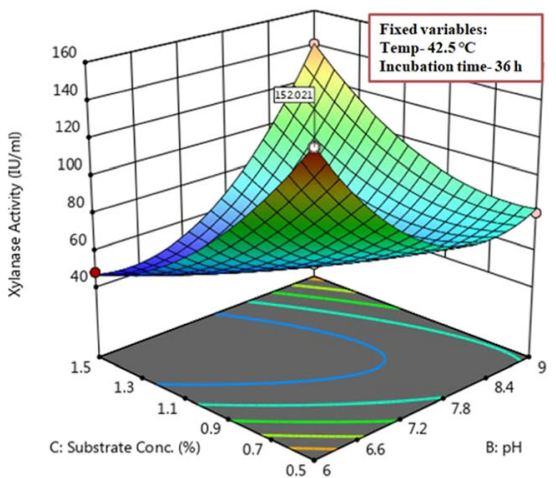

D

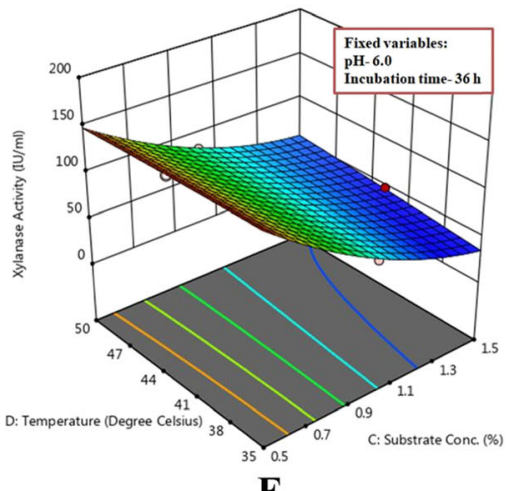

$\mathbf{F}$

Fig. 8 Response surface graph of xylanase activity of the xylanolytic bacterium Pseudomonas mohnii with respect to different experimental factors a vs. pH, incubation time; $\mathbf{b}$ vs. substrate conc., incubation time; $\mathbf{c}$ vs. temperature, incubation time; $\mathbf{d}$ vs. substrate conc., pH; e vs. temperature, $\mathrm{pH}$; and $\mathbf{f}$ vs. temperature, substrate conc. 
xylanase activity from 52.6 to $148.9 \mathrm{IU} / \mathrm{ml}$. The residual plot (Fig. 9) analysis of xylanase activity of the xylanolytic bacterial strain Pseudomonas mohnii represented greater stability in the predicted vs. actual plots and normal residual plots. The distribution of response data from different experimental conditions depicted the equal contribution of most of the factors. The probability plots also demonstrated as much similarity between the predicted and actual xylanase activity.

In the present study, an optimum $\mathrm{pH} 6.0$ was determined in which the highest amount of xylanase (152 IU/ $\mathrm{ml}$ ) was produced. Although at $\mathrm{pH} 9.0,149.9 \mathrm{IU} / \mathrm{ml}$ of xylanase was shown to be produced. In the present study, the production of xylanase was reported for different incubation time periods such as 12,36 , and $60 \mathrm{~h}$. The optimum incubation time and substrate concentration were $36 \mathrm{~h}$ and $0.5 \%$, respectively, upon which the bacterial strain Pseudomonas mohnii showed the highest xylanase activity. The role of temperatures on xylanase enzyme production was determined in the current study, and the results showed maximum enzyme production takes place at $42.5^{\circ} \mathrm{C}$ by the bacterium Pseudomonas mohnii.

Among the different bacterial species studied, a great number of species belong to the genus Bacillus are found to exhibit xylanase activity. However, a review of the literature revealed that a relatively smaller number of species that belongs to the Pseudomonas genus has been reported to show xylanase activity. A comparison of xylanase activity from different species from Pseudomonas such as Pseudomonas boreopolis, Pseudomonas cellulosa, and Pseudomonas sp. WLUN024 is been presented in Table 7 along with the strain of Pseudomonas mohnii bacterium studied in the present work [35-38]. Among the different Pseudomonas strains, Pseudomonas sp. WLUN024 exhibited so far the maximum xylanase activity $190.2 \mathrm{IU} / \mathrm{ml}$ followed by Pseudomonas mohnii (152 IU/ml), Pseudomonas boreopolis $(25.61 \mathrm{IU} / \mathrm{ml})$, Pseudomonas boreopolis G-22 (1.75-2.67 IU/ml), and Pseudomonas cellulosa $(0.73 \mathrm{IU} / \mathrm{ml})$. From these values of xylanase activity, it is apparent that the strain Pseudomonas mohnii is an efficient xylanase-producing bacterium that belongs to a new report which has not been studied before.

\section{Discussion}

Isolation and screening of bacterial strains are a crucial and principal step for the further study of their identification, secreted enzyme assay, and other molecular and biochemical characterizations. In the present study,

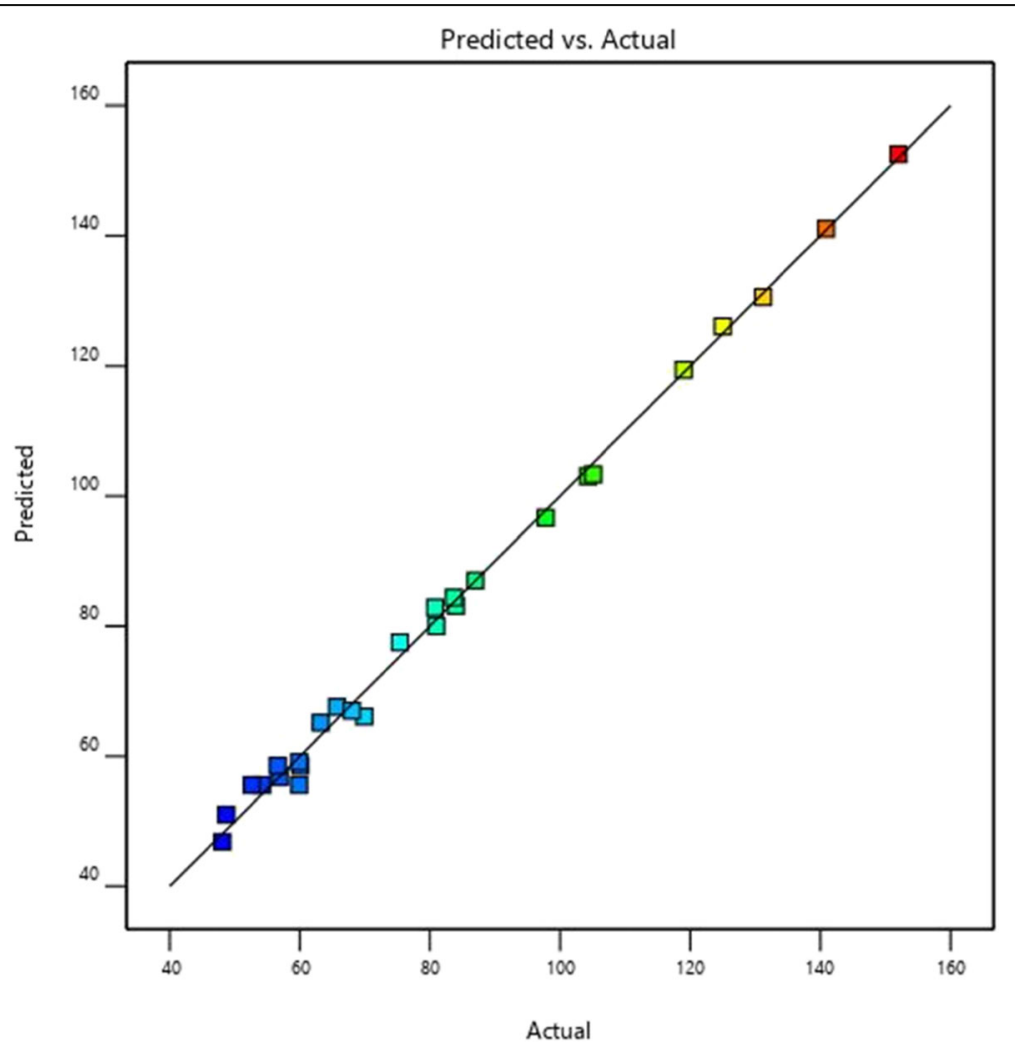

Fig. 9 Residual plots for the xylanase activity of the xylanolytic bacterial strain Pseudomonas mohnii calculated from RSM for the validation of predicted and actual xylanase activity 
Table 7 Comparison of xylanase production by different Pseudomonas sp.

\begin{tabular}{|c|c|c|c|c|c|}
\hline Bacteria & Xylanase activity (IU/ml) & Feedstock & Incubation time/Temperature & $\mathrm{pH}$ & Reference \\
\hline Pseudomonas boreopolis & 25.61 & Wheat bran & $96 \mathrm{~h}, 65^{\circ} \mathrm{C}$ & 6.0 & [35] \\
\hline Pseudomonas boreopolis G22 & $1.75-2.67$ & Wheat straw & 5 days & 8.8 & [36] \\
\hline \multirow[t]{10}{*}{ Pseudomonas cellulosa } & $0.73 \pm 0.07$ & Oat spelt xylan & $30 \mathrm{~h}$ & 7.0 & [37] \\
\hline & $0.65 \pm 0.07$ & Glucuronoxylan & & & \\
\hline & $0.81 \pm 0.10$ & Rye arabinoxylan & & & \\
\hline & $0.91 \pm 0.11$ & Wheat arabinoxylan & & & \\
\hline & $0.21 \pm 0.02$ & $\beta$-Glucan & & & \\
\hline & $<0.01$ & Carbo galactomannan & & & \\
\hline & $<0.01$ & Pectin & & & \\
\hline & $<0.01$ & LB & & & \\
\hline & $0.21 \pm 0.04$ & LB and oat spelt xylan & & & \\
\hline & $<0.01$ & Oat spelt xylan/glucose & & & \\
\hline \multirow[t]{8}{*}{ Pseudomonas sp. WLUN024 } & $118.7 \pm 5.8$ & Hemicellulose & $24 \mathrm{~h}, 37^{\circ} \mathrm{C}$ & $7.2-8$ & [38] \\
\hline & $190.2 \pm 4.3$ & Xylan (Sigma) & & & \\
\hline & $32.2 \pm 1.2$ & Xylose & & & \\
\hline & $31.2 \pm 1.0$ & Wheat bran & & & \\
\hline & $1.2 \pm 0.3$ & Starch & & & \\
\hline & $0.5 \pm 0.3$ & Cellobiose & & & \\
\hline & $1.4 \pm 0.4$ & Sucrose & & & \\
\hline & $2.0 \pm 0.3$ & Glucose & & & \\
\hline Pseudomonas mohnii & 152.0 & Corncob xylan & $36 \mathrm{~h}, 42.5^{\circ} \mathrm{C}$ & 6.0 & [Present study] \\
\hline
\end{tabular}

xylanolytic bacteria were isolated from the forest soil of Simlipal Biosphere Reserve and screened for their xylanase activity using the corn cob xylan. There are different sources of xylans apart from corn cob such as corn fiber, birchwood which are also generally used to isolate and screen xylonolytic bacteria [14]. Similar to our study, isolation and screening of xylanolytic bacteria from the soil samples using a corn cob xylan medium have also been reported by Alves-Prado et al. [39]. It is apparent from the present study that forest soil samples are a reservoir for a large number of xylanase-producing bacteria. It is known that soil is the common source for isolating various industrially important microorganisms [40]. This is also evidenced that forest soil contains organic constituents and minerals which make it a high microbial diversity hub [41]. Earlier studies also indicated that bacterial diversity is abundant in forest topsoils as they are rich in decomposing litter materials [42].

In the current study, xylanase activity has been determined using the DNS method. Similar to this study, Ho [43] also used the DNS method for the estimation of xylanase activity of the bacterium Bacillus subtilis ATCC 6633. Interestingly, the xylanase activity of the bacterium, Bacillus subtilis ATCC 6633 recorded by Ho [43] was $22.07 \mathrm{IU} / \mathrm{ml}$ which is very close with the xylanase activity $(22.5 \mathrm{IU} / \mathrm{ml})$ as obtained from the most potent xylanolytic strain in the present investigation.

The comparison of growth of the bacterium SXB19 in the present study with the results of previous literatures revealed that exponential phase of SXB19 started faster than some already studied Bacillus sp. in which exponential growth started after the incubation of 24 $\mathrm{h}$ [44]. Yadav et al. [45] in their study showed that the exponential growth of Anoxybacillus kamchatkensis NASTPD13 started after $6 \mathrm{~h}$ of incubation and ended at $26 \mathrm{~h}$. These temporal variations in bacterial exponential growth might be resulted from different culture conditions and the amount of bacterial inoculums in the culture broth which has also been demonstrated in the study conducted by Emami et al. [37] where the same carbon source xylan was used the same as the present study. The determination of the exponential phase is crucial to ensure the cells are active. There is an increased enzyme activity in respect to the SXB19 growth phase was recorded which suggested that the xylan was actively used by SXB19 strain during this phase [45]. The growth curve of SXB19 as determined in the present study showed that the stationary phase was delayed that of previously reported result for Bacillus licheniformis 7-2 which started its stationary phase after $24 \mathrm{~h}$ [46]. Similar to our study, the xylanase production by Geobacillus 
stearothermophilus KIBGE-IB29 represented a rapid increase after 24h [47]. Xylanase activity of SXB19 becomes significantly declined during the dye off phase. This decrease in xylanase activity might be resulted from the generation of toxic metabolites during bacterial growth which prevents the enzyme production [48]. Another cause of the decreased enzyme activity might be the feedback inhibition resulted from the high yield of xylose produced from xylan degradation [47]. The reduced enzyme activity at the end of the bacterial growth phase could also be caused by intracellular protease action [49] or may be due to the abrupt changes in the $\mathrm{pH}$ of the media [50].

In the present study, the 16S rRNA sequencing method was used for the molecular identification of bacterial strains [51]. Some bacteria from the genus Pseudomonas having xylanolytic activity over a wide range of environmental conditions have already been reported [22, 35-38]. There was a previous report that the strain Pseudomonas mohnii is also capable of degrading a toxic substance like cholorosalicylates or isopiramic acid, an effluent from paper mill $[52,53]$. However, the present finding of xylanase from the bacterium Pseudomonas mohnii is a new report which has not been studied earlier.

In the present investigation, it has been shown that xylanase activity of Pseudomonas mohnii becomes significantly decreased in the presence of glucose in the growth medium of the bacterium. Rojas-Rejo'n et al. [54] in their study also demonstrated the inhibitory effect of glucose on xylanase activity. The result from their study showed that when $20 \mathrm{mM}$ glucose was added, the xylanolytic activity of the bacterium Cellulomonas flavigena PN-120 decreased by $41 \%$ compared to the culture grown without glucose [54]. So, from the observation of the present study and the work reported from the previous study of Rojas-Rejo' $\mathrm{n}$ et al., it can be stated that the activity of xylanase enzyme is not solely regulated by the substrate xylan and can also be retained or downregulated to a certain level in the presence of different other carbon sources [54].

In the case of nitrogen source, urea has been determined to have the most inducing effects in increasing the xylanase activity of Pseudomonas mohnii among all tested nitrogen sources. In a similar type of study conducted by Seyis and Aksoz [55], it has also been reported that urea is a major inducer in the aspect of increasing the xylanase activity most as an additional nitrogen source compared to other sources like $\mathrm{NH}_{4} \mathrm{NO}_{3}$, $\mathrm{NaNO}_{3}$, and $\left(\mathrm{NH}_{4}\right)_{2} \mathrm{SO}_{4}$. Kumar et al. [56] demonstrated in their study that a low concentration of urea can induce structural changes which enhance the activity of xylanase enzyme from the bacterial species of Chinia.
Thus, it can be stated from the result obtained from the present study and the previous reports that the presence of urea in the bacterial growth media might have some inducing effect to promote xylanase activity.

In the present study, a strong inhibition on xylanase activity of Pseudomonas mohnii by the metal ion sources $\mathrm{MnSO}_{4}$ and $\mathrm{CuSO}_{4}$ has been recorded. Inhibitory effect by these two chemical additives on xylanase activity of Bacillus species was also shown in a previous study by Mamo et al. [57]. $\mathrm{KCl}$ has no significant effect on xylanase activity as recorded in this present study. This observation is similar to the result obtained from the investigation by Archana and Satyanarayana [58] on xylanase production by a thermophilic bacterium Bacillus licheniformis A99.

Optimization of growth factors of the bacterium Pseudomonas mohnii for maximizing the xylanase activity was performed by RSM. The significance of the experimental model designed in RSM is validated by the coefficient of variation (CV). A high percentage of CV represents the lower reliability of any such experimental model [59]. Therefore, in the present study, a lower CV value of $3.22 \%$ implies that the experiments performed are highly reliable. A model can be considered practically reliable and highly significant if the CV is less than $10 \%[60]$.

Doddapaneni et al. [60] suggested that in an ANOVA experiment, the closer the value of $R^{2}$ to 1.0 , the stronger the model and the better it predicts the response of tested enzyme activity according to the designed experimental conditions. If there are many terms in the model and the sample size is small, the adjusted $R^{2}$ value should be significantly less than the $R^{2}$ [61]. In the current study, we have recorded a less adjusted $R^{2}$ value than that of $R^{2}$. Based on the results from ANOVA obtained from the present study, it can be stated that the designed experimental model is highly significant and correctly represents the actual relationship of the effects of variables and enzyme response related to xylanase activity.

Enzyme activity depends significantly on various parameters like $\mathrm{pH}$, substrate concentration, and temperature. The $\mathrm{pH}$ is one of the major factors responsible for the functioning of enzyme systems within an organism [62]. RSM results of the xylanase activity from Pseudomonas mohnii showed that the enzyme has a high substrate turnover rate at $\mathrm{pH} 6.0$ and 9.0. The observations from the result of RSM suggested that xylanase production at different $\mathrm{pH}$ may be an indication that the bacterium Pseudomonas mohnii may have the efficiency to induce multiple xylanase activity at different $\mathrm{pH}$ [63]. Similar to this study, Sá-Pereira et al. [64] reported a $B a$ cillus strain, Bacillus subtilis, which showed maximum xylanase activity at $\mathrm{pH} 6.0$. Xylanase from $B$. 
licheniformis A99 and B. coagulans BL69 was reported to have the optimum $\mathrm{pH}$ of 7 for their maximum enzyme activity [58, 65]. Gupta et al. [66] reported that purified xylanase was functional between $\mathrm{pH} 6.0$ and 10.5 and able to retain more than $70 \%$ of its functionality in this $\mathrm{pH}$ range.

In the current study, an increase in xylanase activity (52.60 to $148.90 \mathrm{U} / \mathrm{ml}$ ) of Pseudomonas mohnii has been recorded at $50{ }^{\circ} \mathrm{C}$ with a decrease in substrate conc. from 1.5 to 0.5. Likewise, Shanthi and Roymon [40] in their study have also shown the highest xylanase production at $50{ }^{\circ} \mathrm{C}$. In another study, Shakoori et al. [67] reported a maximum xylanase production at 45 and $50^{\circ} \mathrm{C}$. Irfan et al. [48] in their study reported that the optimum temperature of xylanase activity was $50^{\circ} \mathrm{C}$ and $\mathrm{pH}$ were 5 and 5.5 by B. subtilis BS04 and B. megaterium BM07, respectively.

\section{Conclusion}

In the present study, a potent xylanase-producing bacterium SXB19 was isolated from the forest soil of Simlipal Biosphere Reserve, Odisha, India, and was identified as Pseudomonas mohnii based on phenotypic and $16 \mathrm{~S}$ rRNA sequencing. Xylanase production of this bacterium was optimized by the response surface methodology using Box-Behnken for the determination of growth parameters $(\mathrm{pH}$, temperature, substrate concentration, and incubation time) in enhancing the xylanase production of the isolated bacterium. The optimization of the xylanolytic activity revealed a higher xylanase-producing activity $(152 \mathrm{IU} / \mathrm{ml})$ by Pseudomonas mohnii at an optimized condition of incubation time $36 \mathrm{~h}, \mathrm{pH} 6.0$, xylan concentration $0.5 \%$, and temperature $42.5^{\circ} \mathrm{C}$. The enzyme production showed an approximately 6.75 times increase over the unoptimized condition. Apart from xylan, starch as a carbon source, urea as a nitrogen source, and metal ion sources like $\mathrm{KCl}$ and $\mathrm{MgSO}_{4}$ also reported to have a significant impact on the xylanase activity of this bacterium. Overall, the bacterium reported in this study was considered to be a potential source of xylanase which can be exploited for industrial application including bioethanol production; however, further studies are required in this direction.

\section{Supplementary Information}

The online version contains supplementary material available at https://doi. org/10.1186/s43141-020-00099-7.

Additional file 1: Fig. S1 Forward 16S rRNA gene sequence of strain SXB19. Fig. S2 Reverse 16S rRNA gene sequence of strain SXB19.

\section{Abbreviations}

SBR: Simlipal Biosphere Reserve; SXB: Simlipal xylanolytic bacteria; RSM: Response surface methodology; KCl: Potassium chloride; $\mathrm{MgSO}_{4}$ : Magnesium sulfate; $\mathrm{MnSO}_{4}$ : Manganese sulfate; $\mathrm{ZnSO}_{4}$ : Zinc sulfate;
$\mathrm{CuSO}_{4}$ : Copper sulfate; $\mathrm{FeSO}_{4}$ : Ferrous sulfate; $\mathrm{NaCl}$ : Sodium chloride; $\mathrm{CaCl}_{2}$ : Calcium chloride; $\mathrm{CoCl}_{2}$ : Cobalt chloride; $\mathrm{NaNO}_{3}$ : Sodium nitrate; $\mathrm{NH}_{4} \mathrm{NO}_{3}$ : Ammonium nitrate; $\left(\mathrm{NH}_{4}\right)_{2} \mathrm{SO}_{4}$ : Ammonium sulfate; IEA: International Energy Agency; DNS: 3,5-Dinitrosalicylic acid

\section{Acknowledgements}

The authors are grateful to the HOD of the Department of Biotechnology, North Orissa University, Baripada, Odisha, India, for providing infrastructure facilities to conduct the experimental works. The authors are also thankful to the Forest and Environment Department, Government of Odisha, India, for the permission of soil sample collection from the buffer areas of Similipal Biosphere Reserve and forest officers and attendants for extending their cooperation during the fieldwork.

\section{Authors' contributions}

MP conducted the major part of experiments, investigated the results, analyzed the data, validated the results with related previous works, and contributed to the writing of the original manuscript and formatting. DPN performed some parts of the methodology, analyzed the data, investigated some results, validated some results with related work, and helped in formal writing. HT supervised the whole work, conceptualized the research, and guided the writing and editing of the manuscript. All authors have read and approved the manuscript.

\section{Funding}

This work did not receive funding from any organization or institution.

Availability of data and materials

All data generated or analyzed during this study are included in this article.

Ethics approval and consent to participate

Not applicable.

\section{Consent for publication}

Not applicable.

\section{Competing interests}

The authors declare that they have no competing interests.

Received: 29 June 2020 Accepted: 1 December 2020

Published online: 11 December 2020

\section{References}

1. Carbon Tracker Initiative (2011) Unburnable carbon - are the world's financial markets carrying a carbon bubble? https://www.carbontracker.org/ reports/carbon-bubble/. (Accessed 13 May 2020)

2. Khan S, Siddique R, Sajjad W, Nabi G, Hayat KM, P. Duan, et al (2017) Biodiesel production from algae to overcome the energy crisis. HAYATI J Biosci 24(4):163-167. https://doi.org/10.1016/j.hjb.2017.10.003

3. EIA IEO (2007) International Energy Outlook 2007. U.S. Department of Energy, Energy Information Administration, Washington DC.

4. Owusu PA, Asumadu-Sarkodie S (2016) A review of renewable energy sources, sustainability issues and climate change mitigation. Cogent Eng 3(1):1167990. https://doi.org/10.1080/23311916.2016.1167990

5. Gomiero A (2015) Are biofuels an effective and viable energy strategy for industrialized societies? A reasoned overview of potentials and limits. Sustainability 7(7):8491-8521. https://doi.org/10.3390/su7078491

6. Zabed H, Faruq G, Sahu JN, Azirun MS, Hashim R, Nasrulhaq A (2014) Bioethanol production from fermentable sugar juice. Sci World J Article ID 957102:11. https://doi.org/10.1155/2014/957102

7. Tana T, Zhang Z, Moghaddam L, Rackemann DW, Rencoret J, Gutierrez A et al (2016) Structural changes of sugar cane bagasse lignin during cellulosic ethanol production process. ACS Sustain Chem Eng 4(10):54835494. https://doi.org/10.1021/acssuschemeng.6b01093

8. Ravindran H, Thangalazhy GS, Adhikari S, Fasina O, Tu M, Via B et al (2015) Production of bio-oil from underutilized forest biomass using an auger reactor. Energy Sources 37(7):750-757. https://doi.org/10.1080/15567036. 2011.613894

9. Pauly M, Keegstra K (2008) Cell-wall carbohydrates and their modification as a resource for biofuels. The Plant J 54(4):559-568. https://doi.org/10.1111/j. $1365-313 X .2008 .03463 . x$ 
10. Balat M (2011) Production of bioethanol from lignocellulosic materials via the biochemical pathway. Energ Conversand Manage 52(2):858-875. https:// doi.org/10.1016/j.enconman.2010.08.013

11. Chundawat SPS, Beckham GT, Himmel ME, Dale BE (2011) Deconstruction of lignocellulosic biomass to fuels and chemicals. Annu Rev Chem Biomol Eng 2:121-145. https://doi.org/10.1146/annurev-chembioeng-061010-114205

12. Karimi K, Taherzadeh MJ (2016) A critical review of analytical methods in pretreatment of lignocelluloses: composition, imaging, and crystallinity. Bioresour Technol 200:1008-1018. https://doi.org/10.1016/j.biortech.2015.11. 022

13. Schomburg D, Schomburg I, Chang A (eds) (2005) Springer handbook of enzymes: class 1. Oxidoreductases IX, EC 1.6-1.8. Springer-Verlag Berlin Heidelberg. doi:https://doi.org/10.1007/978-3-642-36265-1

14. Walia A, Guleria S, Mehta P, Chauhan A, Prakash A (2017) Microbial xylanases and their industrial application in pulp and paper biobleaching: a review. 3 Biotech 7(1):11. https://doi.org/10.1007/s13205-016-0584-6

15. Harris AD, Ramalingam C (2010) Xylanases and its application in food industry: a review. J Exp Sci 1(7):1-11

16. Kim JH, Kim SC, Nam SW (2000) Constitutive overexpression of the endoxylanase gene in Bacillus subtilis. J Microbiol Biotechnol 10(4):551-553

17. Collins T, Meuwis MA, Stals I, Claeyssens M, Feller G, Gerday C (2002) A novel family 8 xylanase, functional and physicochemical characterization. JBC 277(38):35133-35139

18. Pellerin P, Gosselin M, Lepoutre JP, Samain E, Debeire P (1991) Enzymatic production of oligosaccharides from corncob xylan. Enz Microb Technol 13(8):617-621

19. Dodd D, Cann IK (2009) Enzymatic deconstruction of xylan for biofuel production. Gcb Bioenergy 1(1):2-17

20. Subramaniyan S, Prema P (2002) Biotechnology of microbial xylanases: enzymology, molecular biology, and application. Crit Rev Biotechnol 22(1): 33-64

21. Paës G, Berrin JG, Beaugrand J (2012) GH11 xylanases: structure/function/ properties relationships and applications. Biotechnol Adv 30(3):564-592

22. Collins T, Gerday C, Feller G (2005) Xylanases, xylanase families and extremophilic xylanases. FEMS Microbiol Rev 29(1):3-23. https://doi.org/10. 1016/j.femsre.2004.06.005

23. Qinnghe C, Xiaoyu Y, Tiangui N, Cheng J, Qiugang M (2004) The screening of culture condition and properties of xylanase by white rot fungus Pleurotus ostreatus. Process Biochem 39(11):1561-1566

24. Mishra RC, Sahoo HK, Pani DR, Bhandari DC (2013) Genetic resources of wild tuberous food plants traditionally used in Similipal Biosphere Reserve, Odisha, India. Genet Resour Crop Evol 60(7):2033-2054. https://doi.org/10. 1007/s10722-013-9971-6

25. Samanta AK, Kolte AP, Senani S, Sridhar M, Jayapal N (2011) A simple and efficient diffusion technique for assay of endo- $\beta-1,4-x y l a n a s e$ activity. Braz J Microbiol 42(4):1349-1353. https://doi.org/10.1590/S151783822011000400016

26. Miller GL (1959) Use of dinitrosalicylic acid reagent for determination of reducing sugar. Anal Chem 31(3):538-542. https://doi.org/10.1021/ ac60147a030

27. Whitman WB (2015) Taxonomic outline of Bacteria and Archaea. Bergey's manual of systematics of archaea and bacteria. World J Microbiol Biotechnol 21:575-581. ISBN: 9781118960608. https://doi.org/10.1002/9781118960608. bm00024

28. Sambrook J, Russel D (2001) Rapid isolation of yeast DNA. In: Sambrook J, Russel DW (eds) Molecular cloning, a laboratory manual. Cold Spring Harbor Laboratory, New York, pp 631-632

29. Huang X, Madan A (1999) CAP3: A DNA sequence assembly program. Genome Res 9(9):868-877. https://doi.org/10.1101/gr.9.9.868

30. Kumar S, Stecher G, Tamura K (2016) MEGA7: Molecular Evolutionary Genetics Analysis version 7.0 for bigger datasets. Mol Biol Evol 33(7):18701874. https://doi.org/10.1093/molbev/msw054

31. Sharma S, Singh $P$ (2014) Isolation and characterization of galactosidase enzyme producing microbe and optimization of its enzyme activity under different culture condition. Int J Curr Microbiol Appl Sci 3(7):148-155

32. Garai D, Kumar V (2013) Response surface optimization for xylanase with high volumetric productivity by indigenous alkali tolerant Aspergillus candidus under submerged cultivation. 3. Biotech 3(2):127-136

33. Smitha KV, Pradeep BV (2017) Application of Box-Behnken design for the optimization of culture conditions for novel fibrinolytic enzyme production using bovine blood clot by Bacillus altitudinis S-CSR 0020. J Pure Appl Microbiol 11(3):1447-1456. https://doi.org/10.22207/JPAM.11.3.28

34. Mohapatra S, Padhy S, Mohapatra PKD, Thatoi H (2018) Enhanced reducing sugar production by saccharification of lignocellulosic biomass, Pennisetum species through cellulase from a newly isolated Aspergillus Fumigatus. Bioresour Technol 253:262-272. https://doi.org/10.1016/j.biortech.2018.01. 023

35. Lin C, Shen Z, Zhu T, Qin W (2017) Bacterial xylanase in Pseudomonas boreopolis LUQ1 is highly induced by xylose. Can J Biotechnol 1(3):73-79. https://doi.org/10.24870/cjb.2017-000112

36. Guo H, Hong C, Zhang C, Zheng B, Jiang D, Qin W (2018) Bioflocculants' production from a cellulase-free xylanase-producing Pseudomonas boreopolis $\mathrm{G} 22$ by degrading biomass and its application in cost-effective harvest of microalgae. Bioresour Technol 255:171-179. https://doi.org/10. 1016/j.biortech.2018.01.082

37. Emami K, Nagy T, Fontes CMGA, Ferreira LMA, Gilbert HJ (2002) Evidence for temporal regulation of the two Pseudomonas cellulosa xylanases belonging to glycoside hydrolase family 11. J Bacteriol 184(15):4124-4133. https://doi. org/10.1128/JB.184.15.4124-4133.2002

38. Xu ZH, Bai YL, Xu X, Shi JS, Tao WY (2005) Production of alkali-tolerant cellulase-free xylanase by Pseudomonas sp. WLUN024 with wheat bran as the main substrate. World J Microbiol Biotechnol 21:575-581. https://doi. org/10.1007/s11274-004-3491-7

39. Alves-Prado HF, Pavezzi FC, Leite RSR, de Oliveira VM, Sette LD, DaSilva R (2010) Screening and production study of microbial xylanase producers from Brazilian Cerrado. Appl Biochem Biotechnol 161(1-8):333-346. https:// doi.org/10.1007/s12010-009-8823-5

40. Shanthi V, Roymon MG (2018) Isolation and screening of alkaline thermostable xylanase producing bacteria from soil in Bhilai Durg Region of Chhattisgarh, India. Int J Curr Microbiol Appl Sci 3(8):303-311. https://doi. org/10.4172/2167-7972.1000101

41. Agnelli A, Ascher J, Corti G, Ceccherini MT, Nannipieri PG (2004) Distribution of microbial communities in a forest soil profile investigated by microbial biomass, soil respiration and DGGE of total and extracellular DNA. Soil Biol Biochem 36(5):859-868. https://doi.org/10.1016/j.soilbio.2004.02.004

42. Baldrian P, Kolarık M, Stursova M, Kopecky J, Valaskova V, Vetrovsky T (2012) Active and total microbial communities in forest soil are largely different and highly stratified during decomposition. The ISME J 6(2):248-258. https:// doi.org/10.1038/ismej.2011.95

43. Ho HL (2015) Xylanase production by Bacillus subtilis using carbon source of inexpensive agricultural wastes in two different approaches of submerged fermentation (SmF) and solid state fermentation (SSF). J Food Process Technol 6(4):1-9. https://doi.org/10.4172/2157-7110.1000437

44. Yang W, Zhuang Z, Elegir G, Jeffries TW (1995) Alkaline-active xylanase produced by an alkaliphilic Bacillus sp. isolated from kraft pulp. J Ind Microbiol 15(5):434-441. https://doi.org/10.1007/BF01569971

45. Yadav P, Maharjan J, Korpole S, Prasad GS, Sahni G, Bhattarai T et al (2018) Production, purification, and characterization of thermostable alkaline xylanase from Anoxybacillus kamchatkensis NASTPD13. Front Bioeng Biotechnol 6:65. https://doi.org/10.3389/fbioe.2018.00065

46. Seo JK, Park TS, Kwon IH, Piao MY, Lee CH, Ha JK (2013) Characterization of cellulolytic and xylanolytic enzymes of Bacillus licheniformis JK7 isolated from the rumen of a native Korean goat. Asian Austral J Anim Sci 26(1):5058. https://doi.org/10.5713/ajas.2012.12506

47. Bibi Z, Ansari A, Zohra RR, Aman A, Qader SAU (2014) Production of xylan degrading endo-1, 4- $\beta$-xylanase from thermophilic Geobacillus stearothermophilus KIBGE-IB29. J Rad Res Appl Sci 7(4):478-485. https://doi. org/10.1016/j.jrras.2014.08.001

48. Irfan M, Asghar U, Nadeem M, Nelofer R, Syed Q (2016) Optimization of process parameters for xylanase production by Bacillus sp. in submerged fermentation. J Rad Res Appl Sci 9(2):139-147. https://doi.org/10.1016/j.jrras. 2015.10.008

49. Secades P, Guijarro JA (1999) Purification and characterization of an extracellular protease from the fish pathogen Yersinia ruckeri and effect of culture conditions on production. Appl Environ Microbiol 65(9):3969-3975

50. Liang Y, Feng Z, Yesuf J, Blackburn JW (2010) Optimization of growth medium and enzyme assay conditions for crude cellulases produced by a novel thermophilic and cellulolytic bacterium, Anoxybacillus sp. 527. Appl Biochem Biotechnol 160(6):1841-1852

51. Srinivasan R, Karaoz U, Volegova M, MacKichan J, Kato-Maeda M, Miller S et al (2015) Use of $16 S$ rRNA gene for identification of a broad range of 
clinically relevant bacterial pathogens. PLoS ONE 10(2):e0117617. https://doi. org/10.1371/journal.pone.0117617

52. Malfliet S, Justé A, Crauwels S, Willems K, De Cooman L, Lievens B et al (2013) Assessing the xylanolytic bacterial diversity during the malting process. Food Microbiol 36(2):406-415. https://doi.org/10.1016/j.fm.2013.06. 025

53. Cámara B, Strömpl C, Verbarg S, Spröer C, Pieper DH, Tindall BJ (2007) Pseudomonas reinekei sp. nov., Pseudomonas moorei sp. nov. and Pseudomonas mohnii sp. nov., novel species capable of degrading chlorosalicylates or isopimaric acid. Int J Syst Evol Microbiol 57(Pt 5):923931. https://doi.org/10.1099/ijs.0.64703-0

54. Rojas-Rejón OA, Poggi-Varaldo HM, Ramos-Valdivia AC, Martínez-Jiménez A, Cristiani-Urbina E, Martínez MT et al (2011) Production of cellulases and xylanases under catabolic repression conditions from mutant PR-22 of Cellulomonas flavigena. J Ind Microbiol Biotechnol 38(1):257-264. https://doi. org/10.1007/s10295-010-0821-7

55. Seyis I, Aksoz N (2005) Effect of carbon and nitrogen sources on xylanase production by Trichoderma harzianum 1073 D3. Int Biodeter Biodegr 55(2): 115-119. https://doi.org/10.1016/j.ibiod.2004.09.001

56. Kumar AR, Hegde SS, Ganesh KN, Khan MI (2003) Structural changes enhance the activity of Chainia xylanase in low urea concentrations. Biochim Biophys Acta Proteins Proteom 1645(2):164-171

57. Mamo G, Hatti-Kaul R, Mattiason B (2006) A thermostable alkaline active endo- $\beta$-1,4-xylanase from Bacillus halodurans S7: purification and characterization. Enzyme Microb Technol 39(7):1492-1498. https://doi.org/ 10.1016/j.enzmictec.2006.03.040

58. Archana A, Satyanarayana T (1997) Xylanase production by thermophilic Bacillus licheniformis A99 in solid-state fermentation. Enzyme Microb Technol 21(1):12-17. https://doi.org/10.1016/S0141-0229(96)00207-4

59. Joglekar AM, May AT (1987) Product excellence through design of experiments. CFW 32(12):857-868

60. Doddapaneni K, Tatineni R, Potumarthi R, Mangamoori LN (2007) Optimization of media constituents through response surface methodology for improved production of alkaline proteases by Serratia rubidea. J Chem Technol Biotechnol 82(8):721-729. https://doi.org/10.1002/jctb.1714

61. Vellanki RN, Potumarthi R, Mangamoori LN (2009) Constitutive expression and optimization of nutrients for streptokinase production by Pichia pastoris using statistical methods. Appl Biochem Biotechnol 158(1):25-40. https:// doi.org/10.1007/s12010-008-8315-z

62. Gupta U, Kar R (2008) Optimization and scale up of cellulase free endo xylanase production by solid state fermentation on corn cob and by immobilized cells of a thermotolerant bacterial isolate. Jordan J Biol Sci 1(3): 129-134

63. Sharma P, Bajaj BK (2005) Production and partial characterization of alkalitolerant xylanase from an alkalophilic Streptomyces sp. CD3. J Sci Ind Res 64(9):688-697

64. Sá-Pereira P, Mesquita A, Duarte JC, Barros MRA, Costa Ferreira M (2002) Rapid production of thermostable cellulase-free xylanase by a strain of Bacillus subtilis and its properties. Enzyme Microb Technol 30(7):924-933. https://doi.org/10.1016/S0141-0229(02)00034-0

65. Wang SL, Yen YH, Shih IL, Chang AC, Chang WT, Wu WC et al (2003) Production of xylanases from rice bran by Streptomyces actuosus A-151. Enzyme Microb Technol 33(7):917-925. https://doi.org/10.1016/S01410229(03)00246-1

66. Gupta S, Kuhad RC, Bhushan B, Hoondal GS (2001) Improved xylanase production from a haloalkalophilic Staphylococcus sp. SG-13 using inexpensive agricultural residues. World J Microbiol Biotechnol 17(1):5-8 https://doi.org/10.1023/A:1016691205518

67. Shakoori FR, Shokat M, Saleem F, Reaz T (2015) Screening, optimization and characterization of xylanase by locally isolated bacteria. Punjab Univ J Zool 30(2):065-071

\section{Publisher's Note}

Springer Nature remains neutral with regard to jurisdictional claims in published maps and institutional affiliations.

\section{Submit your manuscript to a SpringerOpen ${ }^{\circ}$ journal and benefit from:}

- Convenient online submission

- Rigorous peer review

- Open access: articles freely available online

- High visibility within the field

- Retaining the copyright to your article

Submit your next manuscript at $\boldsymbol{\nabla}$ springeropen.com 